\title{
総会一般 演題演説要旨
}

\section{開会の辞 \\ I 群}

基礎的研究 (1) 座長 広戸幾一郎

(久大教授)

1. 哺乳動物（人，犬，猫，家鬼）

喉頭の比較解剖学的観察

\begin{tabular}{|c|c|}
\hline 広戸幾一郎 & 平野 奏 \\
\hline 高瀬晴朗 & $\begin{array}{l}\text { 天武良規 } \\
\text { (久留米大) }\end{array}$ \\
\hline
\end{tabular}

喉頭の筋, 神経に関しては, 解剖学的, 組織学的, 或 は生理学的研究が多々発表されているが未だ不明の点も 少なくなく, 且つ同種の研究についても研究者により相 反する成績さえ観られる現状である。乙れは実験動物, 実験方法, 実験条件等の差によるものとも思われるし, 一, 二種の動物についての限られた実験方法から早急に 結論を導出する傾问があるためとも考学られる. そこで 我々は喉頭の筋, 神経生理の解明には, 喉頙の系統解剖 学的研究が不可欠な一手段である之確信し, 各種動物の 比較解剖を行なっているが今回は人, 犬, 猫, 家稞につ いての成績を報告する, 尚, 実験は全て立体双眼顕微鏡 下に行なった。

成績の概要は次の如くである.

〔I 内晚頭筋

（1）動物間に著明な差異が認められるのは輪状甲状筋 披裂筋, および披裂肹頭蓋筋で, 甲状披裂筋, 側輪状披 裂筋，後輪状披裂筋には差がみられない。

（2）輪状甲状筋は人では直部と斜部苍認め発育良好で ある. 犬, 猫では直部に相当するものを認めず, 全ての 筋線維は斜走している. 犬では本筋の発育が極めて良い 家躳では直部に相当するもののみで発育は弱い。

（3）披裂筋は人, 猫では略々同一形態を示し, 横, 及 び斜披裂笳をみるが，犬，家象では著明な差異が認めら れる。即ち，犬では左右の披裂軟骨を結ぶ所謂横披裂筋 は見られず，披裂軟骨後外側縁から同側軟骨後内縁に集 剣する 1 筋群をみるのみである. 又, 家鬼では斜披裂筋 の発達著明で, 横披裂筋の一部筋束は輪状軟骨上縁に附
着し特有の形態を示している.

（4）披裂喉頭蓋筇は人，犬，猫で認められ，特に犬で は発育良好である，家鬼では本筋を認め難い，

[II]喉頭神経

（1）上㗹頭神経：人，犬では舌骨甲状膜を貫いて喉頭 内一進入分岐するが家鬼，猫，では甲状軟骨板後上部の甲 状孔から進入する. 各動物共前, 中, 後の 3 枝に分岐し 支配領域も大差はない。即ち, 前枝は喉頭蓋, 中枝は披裂 用状皱壁を中心として声門より上部の喉頭内外の粘膜, 後枝は披裂筋表面の粘膜および横筋と披裂軟骨後面を滑 走して披裂軟骨内側面の粘膜即ち, 声門後下方に分布す る. 尚，後枝は，いわゆる Galen の吻合に連る．三枝 共に他侧側枝との吻合は認めない，尚，人に於いては後 枝の 1 分枝は披裂外倒部で, 下䐅頭神経の横筋枝之吻合 しているが，他の動物ではかかる吻合を確認していない。

(2) 下咽頭神経：犬，家鬼では主として喉頭内分皮を 行ない，人，猫では堠頭外分岐が主体である。普通，家 石奄除いて人，犬，猫では，その分岐は前後の 2 岐で夫 々内堠頭筋を支配する枝と Galen の吻合へ連る枝とな るが,家鬼では,Galen の吻合への分岐は喉頭内で下喉頭 神経本幹の後筋外測部で分岐されて比較的短小である. 尚, いづれの動物でも, Galen の吻合から内䒨頭筋への 線維は出していない.

2. 電気的構音器官模型 Electrical vocal tract analog の試作について

$$
\begin{aligned}
& \text { 広戸幾一郎 平野 実 ○宫城 平 } \\
& \text { (久留米大) } \\
& \text { 中島 亨 太田栄二 } \\
& \text { (九州工大) }
\end{aligned}
$$

構音障害の研究には, 1) X線的に構音器官の静的なら びに動的形態異常を検查する方法, 2) 鼻腔, 口腔, 咽頭 各部の語音発声時の気圧を測定する方法。 ${ }^{3)}$ 口唇, 舌, 軟口蓋, 喉頭各筋の語音発声時の筋電図を同時記録して 
之を経時的に検討する方法，4）構音障害者の音声を録音 し, 之を Sonagraph で分析して, その障害部位を推察 する方法等があるが，K. N. Stevens によつて報告せら れた electrical vocal tract analog を用いてする方法も その一つである.

我々は，K. N. Stevens の論文を参考にして，その作 成を試みた（図1）．特に創意した点は，1）喉頭原音に相 当する鋸歯状波発振器の基本周波教を可変とした。 ${ }^{2)}$ 工 ニバイブレーターI， II，IIIのつくる矩形パルスウ7 $7_{1} 7_{2}$ 78 (図 2), 即ち有声子音音節の先行波, 有声子音波, 後 続母音, 無声子音音節の無声子音波の継続時間を可変と した。 ${ }^{3)}$ vocalract 等価回路はL.C. $\pi$ 回路の縦続で. K. N.Stevensの方法を用いているが，その任意の部占り音 声を誘導出来る様にした。即ち，原音が曰より発せられ るまでに，如何に修飾されて行くかがわかる様にした。 4) 音声合成期間中の鋸崡状波, 雑音波の振巾变化機構も 任意に設定し得る様にした。ことなどである。

電気的構音器官模型に上る音声の合成で最も難しいの は，有声子音音節に於ける移行部であるが，此の点に関

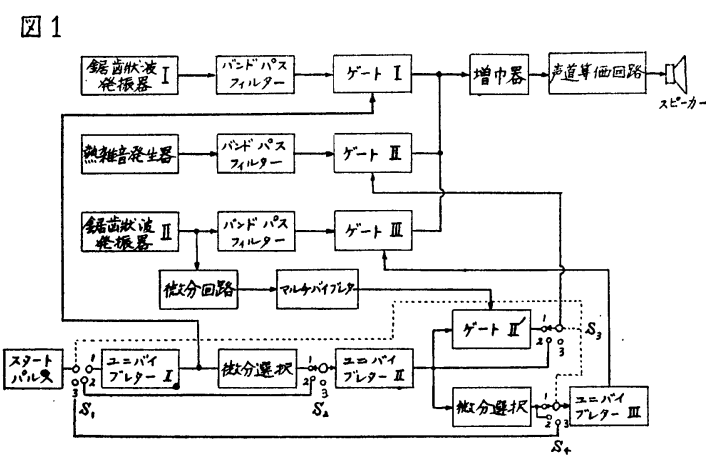

四2, 有声子音蓈の合成

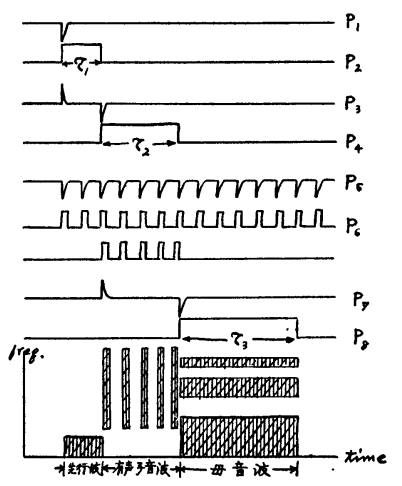

しては, 頭部食道癌剔出手術後の患者に対して人工喉頭 を使用させた実験で，先行波が強力であれぼ移行部はな くとも語音の明暸度, 及び至然度に変化が生じないとと を知っているので, 図 2 亿示す如く, 有声子音音節の構 成より移行部を除外した。母音音節, 無声子音音節の構 成は Sonagram に示される通りとした。

3. 言語発達検査の試み

鈴木篤郎 ○田中美郷 前沢恵子 (信 大)

言語障害児の検査に当って最も戸惑う問題の 1 つは言 諤の検查を如何にするかということである，従来わが国 ではこの方面の研究は甚だ少なく, 加藤, 牛島, 石川氏 等の検査法加発表されてはいるものの我々臨床家に役立 つ検查法は殆どない，小児の言語障害の検查に当っては

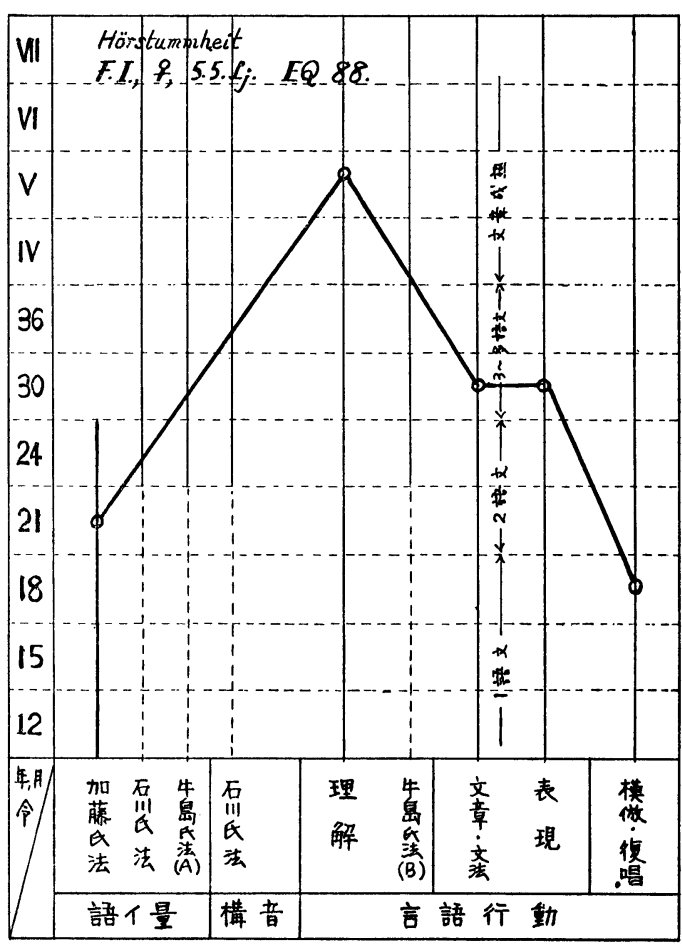

言語発達輪郭 $(1-7$ ) 
少なくとも(1)言語の発達程度 (正常な言語発達のPattern に比してどの程度おくれているか) (2)障害程度 (正常な 言語発達の Pattern からどの程度に, 又どの様に偏奇し ているか）をみる必要があると思う，我々は今回はてれ ら検查の 1 つとして言語発達検査法なるものを試みた。 検查内容は(1)噡彙量，(2)構音又は発音，(3)官語の理解・ 記憶, (4)表現・文章文法, (5)模做・復唱等の項目に分け て観察し学令期迄を大きく 3 段階に分けた. 即ち第 1 段 階はいわばてとばの発達の前段階に当る 1 才以前の状態 であり, この段階では聴覚機能の発達总中心に, 発声, 喃語, 模倣, 理解, 表現等を月単位に評価する. 第 2 段 階は1〜3才の言語発達の最も華かな時期であり, 語彙, 構音等の量的, 質的発達之共に理解, 文章 - 文法, 表現, 模倣, 復唱等の言語行動をみる. 第 3 段階は 3 才以後の 言語の成熟期であるが娭査項目は第 2 段階と殆ど同じで ある. 別表には 5 才 6 カ月女児の聴咡の 1 例を示してあ る.

ての様に検查内容は広範に亘っているが, 本検査法の 基礎となるべき資料が甚だ不充分である現在, 充分満足 のゆく検査法の確立は望むべくもないが，しかし言語障 害児のプロフィルを把握するには便利であるので将来改 良すべき点なども含めて検討したい。

\section{4. 乳児の音声（第 1 報）}

\section{岡村正美 沢島政行 (東大・音声言語障害科) 藤田 尚 安藤由典 (N H K 技研)}

うぶ声, 叫声期から言語発生期にいたる乳児の音声活 動には，その間に見られる著明な身体的精神的発達と関 連して極めて興味深いものがある. われわれは呼吸開始 を示す反射運動といわれるうぶ声から，いかにして伝達 手段としての音声に発展して行くかを音声学的に観察し つつあるが，今回は数例の乳児の音声を約半年間経時的 に観察した.

被検児の音声は Tape Recorder に記録し，てれを Sonagraph 及び Level Recorder を使用して分析した。 その結果を検査時の被検児のわかれた環境及び感情と関 連させて基音とその変動の状態, 声域, 調子と強弱の変
化, 発声の Rhythm 等について観察しその知見につい て報告した。

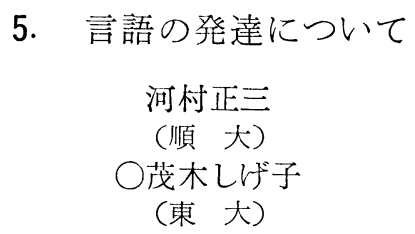

言語発達遅滞児を正しく診断し, 適切な治療を施すた めに，正常児の言語発達を調查検討した，対称は都内の 幼稚園児3才〜5才まで107名, 調査形式は質問用紙に依 る。最初に意味のある言葉を用いたのを始語年令とした。 全例の $73 \%$ は生後 1 年以内に始語があり, 最小年令は 5 カ月であった。運動機能(歩行開始)と始語年令の関係をみ ると言葉の方が早かったもの63\%，同時であったもの 85 \%，言葉の始りの方が遅かったもの $28.5 \%$ あっった。言 葉の始りに用いられた発音は唇音 $(\mathrm{P}, \mathrm{b})$ が一番多く, ついで, 通鼻音 $(m, n)$, 母音となっている. 言葉の内 容に関しては, 食物が圧倒的に多い。言語発達を詳しく 記録した 8 例を検討した結果では, 1 年4カ月頃, 急激に 語菓が増加するととが解かった． 2 語文の使用は始語年 令から8〜9カ月後に始るものが7例であった. 2 語文の 始りと,歌の始りが同時期であったものが 5 例であった。 ての 8 例の記録に基いて, 質問紙を作り, 幼稚園児に再 調査を行なったとてろ, 語彙の増加年令, 2 語文の始り, 歌の始り等について，同じ様な結果を得た。 


\section{II 群}

基礎的研究 (2)

座長 石 倉 武 雄 (順天堂大教授)

6. 7. 8. 中学生の音声

藤田馨一○米山交明 沢島政行 ○茂木しげ子 ○小林武夫 岡村正美 (東大音声・言語障害科)

帆足环也

（芸 大）

I ）——喉頭の形態学的検討

年令と声の関係については, 古来音声学的に, あるい は形態学的に幾多の研究がある.

今回我々も思春期を中心とする年令屏について音声学 的及び形態学的な検査を行ない, 若干の知見を得たので 報告する。

検査対象は東大附属中学の $1 \cdot 2 \cdot 3$ 学年全員で男女夫 々 174名. 172名計 346 名である. 検査方法注予め生徒に 配布して, 各自に記入させた別紙の如き調查用紙を用い 堠頭検查は東大音声言語外来担当医数名が，乙れにあた り, 声の検查にはテープレコーダー, オルガン夫々 2 台 づつ使用し，芸大の声楽專門家 2 名の援助を得て録音 し，後で声を再生して，全員で聴きながら検討を加党 た。検査成績で，話声位および声域と年命との関係，女 生徒の月経と声の変化との関係については興味ある結果 を得たが, 後者にゆずり, とてでは, 喉頭の形態学的変 化と年令および声との関係について検討した。先ず各項 目別についての実数を表に示す.

(1) 声带病変の認められたもの. (学年別, 性別)

(2) Mutations dreieck の認められたもの

(3) Epiglottis の型別人数. ( I . II. III. 型)

(4) Adam's apple の有無. (学年別. 性別) (表, 略)

更に上記検査項目について相互に関連のありそうなも のをあげ検討した。

(1) 変声の有無と声帯所見の関係.

(2) Mutations dreieck と変声の関係.

(3) Mutations dreieck 々嗄声の関係.

(4) Mutations dreieck と話声位の関係.

（表, 略)
声と川のど"の検査用紙

1962. 5

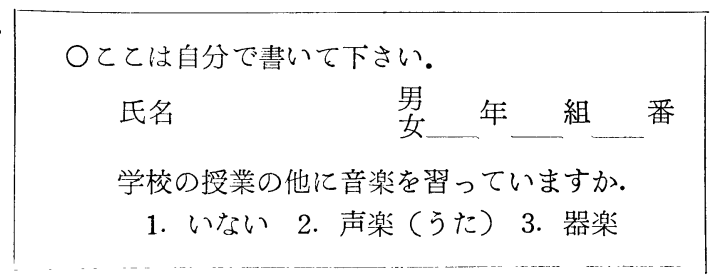

O Tape Recording (生理的声惐)

○男 EFGA H c d e f g a h c $c^{\prime} d^{\prime} e^{\prime} f^{\prime} g^{\prime} a^{\prime} h^{\prime}$ 女 afgah c $c^{\prime} d^{\prime} e^{\prime} f^{\prime} g^{\prime} a^{\prime} h^{\prime} c^{\prime \prime} d^{\prime \prime} e^{\prime \prime} f^{\prime \prime} g^{\prime \prime} a^{\prime \prime} h^{\prime \prime}$

○検查難易

○リンパ節 + , - $\bigcirc$ Adam's apple + \pm -

○扁桃 正常 肥大 炎症 扁摘

$\bigcirc$ 喉頭蓋 $1 . \wedge 2 . \wedge 3 . \curvearrowleft$

○声带 正常 充血 浮腫 結節

$\bigcirc$ Mutations dreieck + -

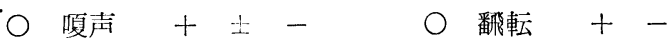

0 変声 + \pm-

II ）——音声学的検討—

喕声：男子において，僅かながら認められる．各学 年とも同程度であるが，女子においては一周少ない。

変声：男子では高学年になるにしたがい，変声を経 験するものが多い，女子では，すでに中学入学以前に変 声を終了している者が半数以上をしめ, 二学年では大多 数が変声觉終っている.

声の䧽転：女子では低学年に多く, 男子では二学年 に多い.てれらは, 変声の途中にあるものと考えられる.

地声と裹声： 裏声発声の可能なものについては，女 子の方がはるかに多く，高学年になるにつれて増加する。 これにくらべて，男子では，裏声発声可能者は少ない，

話声位：女子では各学年とも, 安定した話声位をも つが，男子では，高学年になるにつれ低下する。

Mutations dreieck と話声位との関係を男子について しらべると，Mutations dreieck のあるものの平均の話 声位は，各学年の平均の話声位と近似関係にある。

Adam’s apple の判然とするものについては，その話 声位は全体の平均より低い。

声域：女子では高学年になるにつれ，声域の巾は一 定してくるが，男子では各学年ともバラつきが多い。 
声域の上限，下限をみると，女子で注年令的動摇が少 なく, 男子では上限, 下限とも低い方移動し, 三学年 になると安定してくる.

III）一女生徒の変声について——

男性の変声に関する研究は種々行なわれているが，女 性関する研究は少ない。私共はてのたび, 女生徒の変 声と月経との関係を中心として調査を行なった，刘象女 生徒の中で，すでに月経のあるものは 1 年生 $50 \% ， 2$ 年 生 $85 \%, 3$ 年生 $97 \%$ であり, 変声ありと判断されたもの は 1 年生70\%，2 年生 $88 \% ， 3$ 年生 $99 \%$ であった。すな わち, 各学年とも変声しいる生徒の数は月経のある生徒 の数より多く, 月経のあを生徒は全て変声しているとと がわかった。これに反し変声はしているが初潮をみない という生徒が 1 年生 $20 \%, 2$ 年生 $0.3 \%, 3$ 年生 $0.2 \%$ 亿 認められる．このととから月経開始以前に変声が起るも のが多いのではないかと考光られる。話声位についてみ ると, 月経のある生徒の $93 \%$ が $\mathrm{c}^{\prime}-\mathrm{d}^{\prime}$ 光の間化あり, 変 声済みのものの $88 \%$ が $\mathrm{c}^{\prime}$ - $\mathrm{d}^{\prime \prime}$ \#の間にあるととが喼めら れた．襄声の使用と月経との関係をみると，月経のある もののすべてが裏声を出すととが出来る. 月経がなくて
も襄声の出せる生徒があったが，乙れは，変声はしてい るが初潮を見ないという生徒の数と一致していた。声域 については, 年令とともに広がっており, 月経のある群 は25〜35半音に集中し, 月経のない群ではばらつきが著 明であった。声帯所見と月経との関係では, 声帯に浮腫 炎症，肥擪力゙認められたもの83\%は変声しており，その

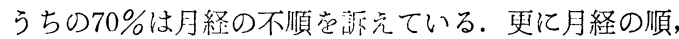
不順と声带所見との関係をるるために, 最近 6 力月以内 に初潮を経験した生従について観察したところ, 半数以 上に病的所見が涩められた。又検査当日月経中であった 8例のうち4例に病的所見が認められた。

9. 日本語母音のフォルマント に関する研究（第一報）

$$
\begin{aligned}
& \text { 高橋宏明 } \\
& \text { (京大音研) } \\
& \text { ○林 律 } \\
& \text { (京 大) }
\end{aligned}
$$

\begin{tabular}{|c|c|c|c|c|c|c|c|c|c|c|}
\hline \multirow{2}{*}{ 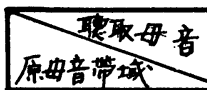 } & \multicolumn{3}{|c|}{ 男 } & \multicolumn{2}{|l|}{ 声 } & \multicolumn{5}{|c|}{ 女 声 } \\
\hline & \% & オ & $\bar{r}$ & $I$ & 1 & ウ & † & $\mathcal{P}$ & $I$ & 1 \\
\hline $300=425$ & 1 & 2 & & & & & & & & \\
\hline $\begin{array}{l}425-600 \\
600-850\end{array}$ & & 11 & & & & & 14 & & & \\
\hline $850-1200$ & & & 7 & & & & 1 & 2 & & \\
\hline $1200-1700$ & & & 5 & & & & & 11 & & \\
\hline $1700-2400$ & & & & & 5 & & & & & \\
\hline $2400-3400$ & & & & & 14 & & & & & 13 \\
\hline $3400-4800$ & & & & & 15 & & & & & 15 \\
\hline
\end{tabular}

日本語母音のフォルマントに関しては, フーリエ解析 ソナグルム等による多くの研究があるが，各研究者によ
(ウ)

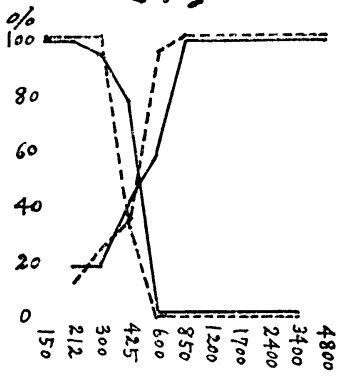

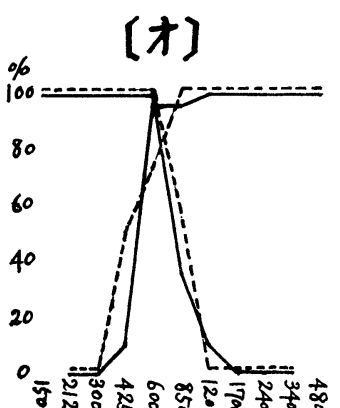

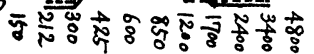
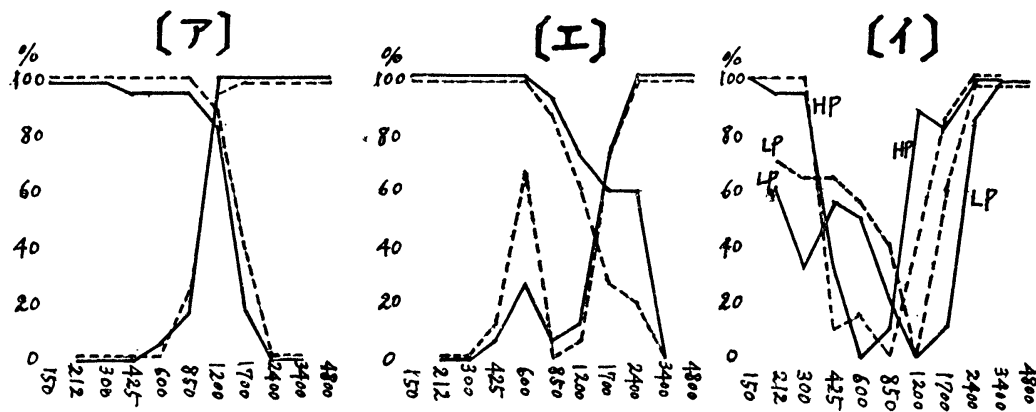

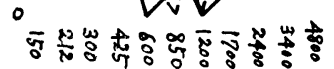


ってその值がまちまちであり, 又, 明瞭度検查の立場か ら行なわれた研究は非常に少ない, そてで我々は, 明膫 度検查によってフォルマントを検討し, 出来ればその帯 域を測定したいと考光，その基礎的研究として次のよう な実験を行なった。

○原録音 21 才〜35才の構音に異常のない男性 3 名,

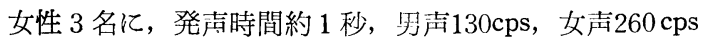
附近のピッチにて, 日本語母音アイウエオを発声させ,

てれをテープに録音した。

○母音の周波数成分のどの辺りに特徴带域が存在する かを調べるため，リオン SA 2701型 Audiofilter による band-pass filtering を行なった. 男声では106cps〜4800 cps を11区間に，女声では 212cps〜 4800cps 范9 区間に 切断して録音し，てれによって得た 300ケの録音を16名 の明瞭度クルーに聴取させた. 16名中 12 名以上の答えが 一致すれば $\mathrm{X}^{2}$ 法によって $5 \%$ 以下の危険率で, 半数以上 のものがその母音ときいたといえるわけで, 明暸度の評 価に当っては, percentage ではなく，ての検定に pass するものを有意として採用した，その結果聴取された母 音種は原母音種と無関係で，带域と密接な関係にあるこ とが判明した (附表参照). 但し〔ウ〕〔エ〕に聴取され たものは非常に少なかった。

○ High pass 及び Low pass 晴線による研究は多く あるが, 一応ての面でも検討すべく, 男女夫々 2 名を選 び， 5 母音の HP 及び LP filtering を行ない, 明瞭度 曲線を作製した。附図には男声の場合のみ示した。関口 氏等の data では, [エ][イ〕の場合も, ての図の[ウ] 〔オ〕〔ア〕型を示しているが，我々の dataはかなり異 った様相を示し，〔エ〕[1]が単一フォルマントでは形 成され難いてとを明瞭に示している。

10. 母音基音波の時間的構造

\section{○太田文彦 細田岩雄}

（京 大）

electronic timer を用いて母音を断続し, その断続率 を基音周波数に一致せしめると, Fig 1 の如く母音の一 定部分のみのくりかえしの音が得られる。(Fig 1. 中段) この sound time の長さを $0.5,1.0,1.5,2.0,2.5$, $3.0 \mathrm{msec}$ とした. 次にとの sound time を silent とし silent であった部分の波形を得る様に timer を改造し， silent time の長さ党上記と同じく $0.5,1.0,1.5,2.0$, $2.5,3.0 \mathrm{msec}$ とした. (Fig 1. 下段)

てれらの音を 5 名のクルーに聞かせ, first choice お よび second choice 苍行なわせ, second choice のない ものは first choice に2を与え, first choice 及び second には夫々 1 を与えて 5 名のクルーで計10を $100 \%$ として 明瞭度を計算した。（Fig 2 及び Fig 3) Fig 2は sound time 觉 0.5 から $3.0 \mathrm{msee}$ まで変化したときの明瞭度の 推移觉示し, Fig 3 は silent time 范変化したときのを 示方.アイエは比較的明瞭度が良いが, 後半を silent した場合も前半を silent にした場合も，ウオでは明瞭 度は余り良くない，即ちアイエでは基音波の一部のみで も明嘹度は良くなるが，ウオでは基音波全体がなければ ウオと聞てえないと考えられる。

また rating response を行ない, その音声の明瞭さを 4 段階に rate し検討した。

明瞭度試験による他, ソォグラフを用いてその音の分 析を行ない, 明瞭度試験の成績と併せて考察を加えた。 (Fig 4 のソナグラムは, オの sound time $0.5 \mathrm{msec} の$ もの定す.)
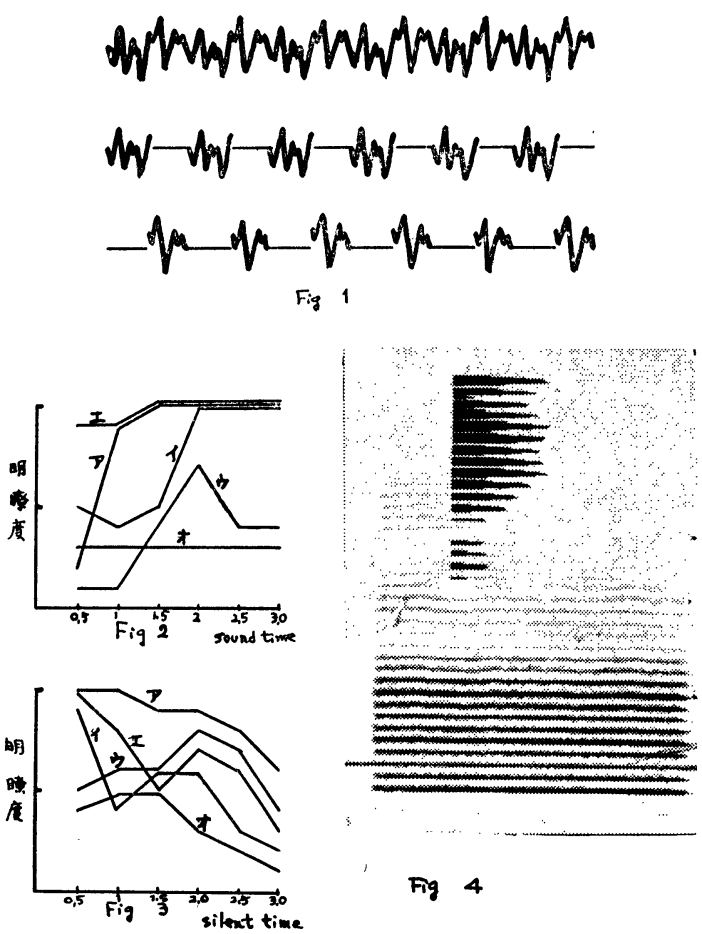


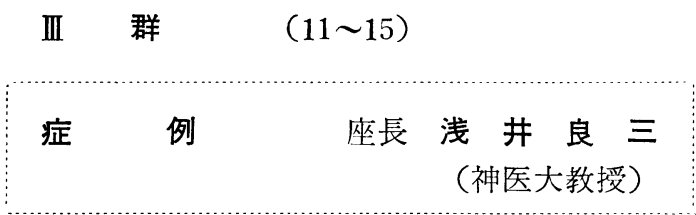

11. 音声衰弱症の一例

柳原尚明 ○小池靖夫 杉山 美 (京 大)

症例は 51 才女, 教師。初診昭昭和 36 年 9 月 22 日. 主 訴：声が出にくいとと. 既往歴：33才肺浸潤及胸膜炎 46才，骨粗鬆症. 家族歷：特記すべきものなし.

現病歴：約1年前食欲不振，呕吐等を来たしたので， 某医を訪れ，約 3 週間ホルたン注射(詳細不明) 苍うけ たところ，上記の諸症状は軽快したが，声が出にくくな り，夕方になるとその程度が強まる様になった。この発 声困難は次第に増強し，一日中声が出にくくなるに至っ た.また，夕方には $37^{\circ} \mathrm{C}$ 前後の微熱を来すのを常とし た. 声の質も粗雑になったと感している。2・3力月前, 内科を訪れたところ甲状腺機能低下といわれ，甲状腺末 投与等の治療をうけたが，音声は恢復せず，障寒が進行 する椂に思うので来院した。疲労し易いが, 呼吸困難, 運動障害等はない。咳, 疢もなく, 嚥下障害もない。

初診時現症：体温平常, 脈膊 $65 / \mathrm{min}$, 血压最高 117 , 最低 70 , 呼吸 $17 / \mathrm{min}$, 体格中等大, 骨格稍虚弱, 䫓頸 部異常なく, 胸部にも打聴診上特記すべき所見を認めな い. 腹部四肢潩常なく, 未稍神経系統汇特記すべき症 候を認めない。

局所所見：耳では左䜵膜に，慢性中耳炎係る陳旧 性の穿孔があるが，炎症所見は認められない，その他に 特記すべきものなく鼻, 咽頭正常. 喉頭では声带は稍細 長く, 発声時に細い線状の間隙苍認めるが, 両側とも運 動正正常であって, 発赤, 腫脹, 結節等の罢常所見を認 めない.

音声所見：声域讨著名に狭少化し，( $\left.\mathrm{a}^{\prime}-\mathrm{c}^{\prime \prime}\right)$ 頭声は 認めらそない, 呼気持続時間15秒, 発声持続時間 8 秒で いずれも短縮し, 嗄声(十)である.

検査所見：血沈正常, 胸部乙線上右肺上野に石灰化 病巣一つを認める他, 異常所見なし. 肝機能, 腎機能正 常, 血液所見では軽度貧血, 血清蛋白分屑では $\mathrm{A} / \mathrm{G}$ 比 1.02 で軽度の炎症像があり, 血中コレステロール值及 P. B. I 等に於いてはでく軽度の甲状腺機能低下が認め
られるが，基礎代謝率は+2.0\%で正常である. その他， 尿中 $17 \mathrm{KS}, 17 \mathrm{OHCS}$, 定量はじめ多くの検査を行なつ たが，著明な内分泌機能障害は証明されなかった。とて ろが，呼吸計を用いて呼吸機能検查を行なったとてろ， 次の様な興味ある結果を得た。 即ち, 肺活量 $1960 \mathrm{cc}, 乙$ の予測值は 2360cc であるから $83.0 \%$, 分時最大換気量 (M. B. C.) $37.1 \mathrm{~L} / \mathrm{M}$ で予測值の $50.9 \%, 1$ 秒量 $1080 \mathrm{cc}$ で 1 秒率 $75.9 \%$, A.T.I. $26.7 \%$. 気速指数 (A. V.I.) 0.61 で著明な閉塞性障害と判定された。即ち, 毛細気管 枝細気管枝に全般的な閉塞が生じていると考えられるの である.

音声衰弱症は機能的発声障害に属するものであって， 声には障害があるが音韭器官には著明な病変がない場合 の一つであるとされている. 本症例も著明な音声障害に 比して侯䫓病変は微少であり, 音声衰弱症と考光られる ものである. 音声家弱症は然し, その原因が多岐にわた り, 必ずしも明かでない場合が多く，また殆んぞ常に精 神神経病性素因が基盤になっているとされているが，上 述の一例は明かに呼吸器系の器質的病変が原因と考光ら れるものである，われわれは上の検查成績芝供覽し，機 能的発声障䆵彰断に際しての呼吸機能検査の重要性につ いて述へ，符下の考察芭加气る。

\section{2. 幼巟失語症の 3 例}

服部 浩

（神戸医大）

幼児の失語症は成人に比して回復しやすいといわれて いる. 我々は第 I 表の如き症例を経験したが, その余後 の比較的良好な理由として次の如き推論を行なった。即 ち1ー3才以下で利手が未だ確立していない段階では言語 中枢の機能も左右半球間に大差なく (勿論, 先天的に一 側に多少の優位がある場合も考えられる) その後に利手 の確立につれて次第に一方の半球に機能が局在してゆく が6〜7才以下では未だ言語中枢の機能的分化が未完成で 利手々同側の半球でも従属的ではあるが言語機能関与 し従って左右何れの障害でも失語症を来しうるが又一方 他側の代償が比較的速かであるため余後が良好になるる 
のと思われる. この裏付けの一つとして文献より第 2 表 の如く, 生来左利の 40 例を集めた. それらでは左右何れ の半球の障害でも失語症を来しているがてれは生来左利 の人は右利と異なり必ずしも右側大脳半球にのみ言語中 枢が局在せしない，何故なれば生来の左利は後天的に右 利になるよう教育されることが多く，その場合には両手 利になる傾向が強く, 言語中枢も両側性となり(勿論一 方が優位に立っているてともある) 従って一側半球の障
害で言語障害がわてっても言語中枢が一側のみに局在し ている場合に比べて障害の程度が軽く, また機能の代償 (回復)も速かにおてりうるといわれている. 我々の症例 は何れも右利であったが, 言語機能の回復は表の如く可 成り急速に行なわれた.ただ原因疾患の後遺症として知 能がやや低下し, 第2, 第3例では右手指の細かい運動麻 瘦か残存している.

\section{第 1 表}

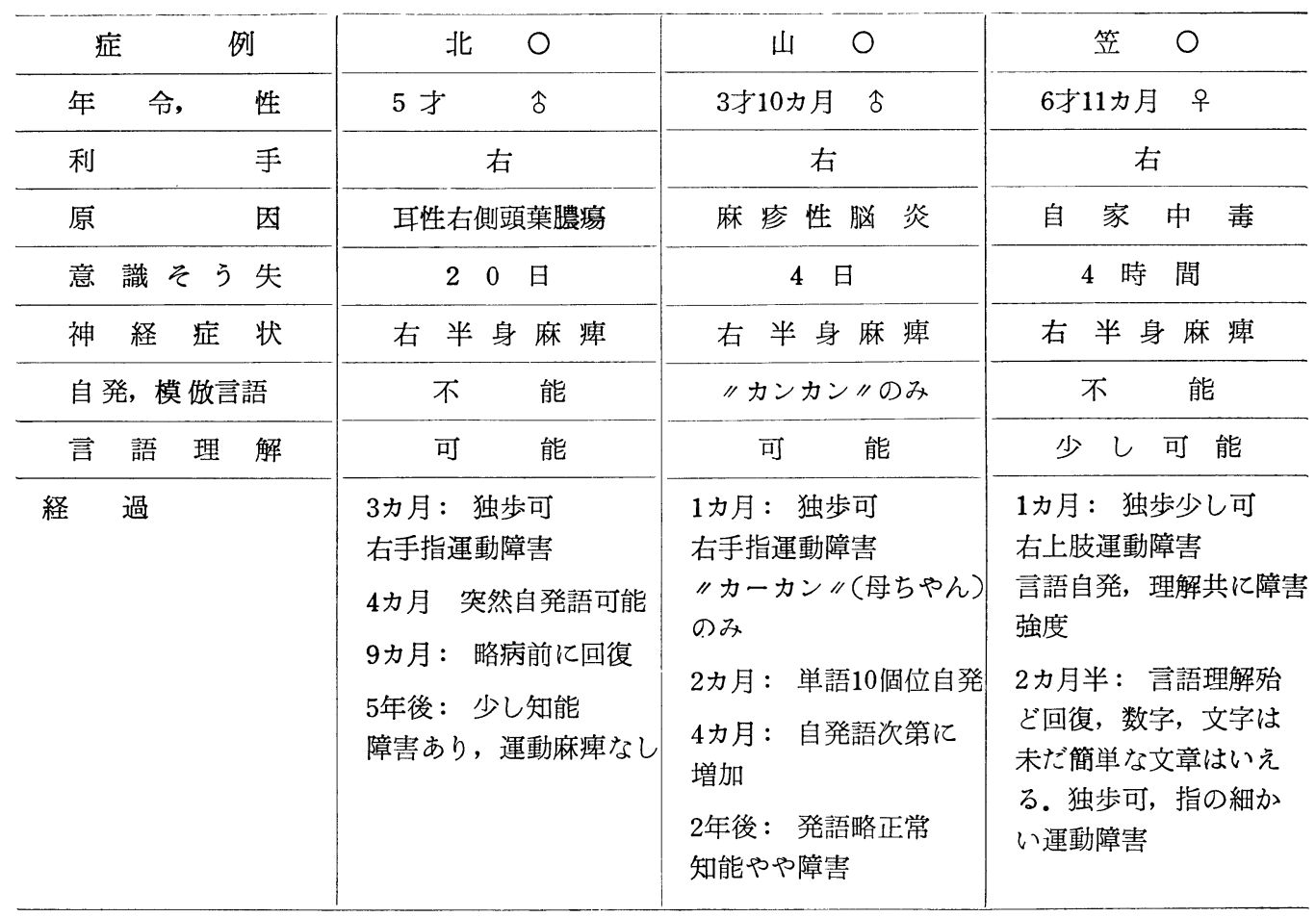

第 2 表 左利の Dysphagie (Aphasie) 症例

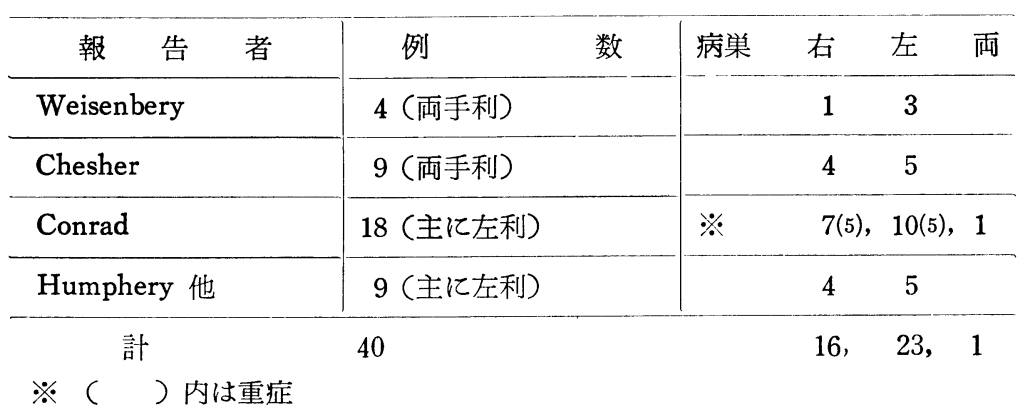


13. 精神壟を思わせた聴覚言語 障害児の 1 例

鈴木篤郎 田中美郷 ○前沢恵子 (信 大)

従来聴㗂は運動性と感覚性の 2 つ分けられているが 最近は失語定覚に由来する精神㜔なる語が用いられるに 及んで聴䴕というのは運動性聴梧だけに限られるべきで あるといわれる。一方以前より感覚性聴嵒ないしは精神 䆍といわれて来たもの苍経過觉追ってみると，多くの例 に高音部に聴力障害があったりしてての疾蚛の存在性を 疑問視する人すらあるが，いずれにせよ綿密な聴力検查 なしにはこの疾患の診断は極めて困難である。我々も当 初精神毼と診断したが細密な聴力検查の結果興味ある事 実を発見したので報告する。症例10才 5 力月女，主訴難 聴言語障害. 家族歷に異常なし.

既往歴：母体妊娠中妊娠腎がひぞく肺水腫併発．鎮子 分婏, 仮死産, 体重650斥.

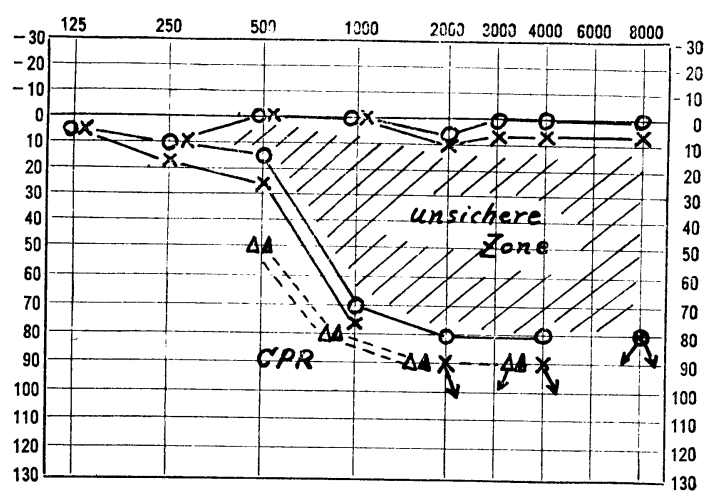

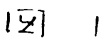

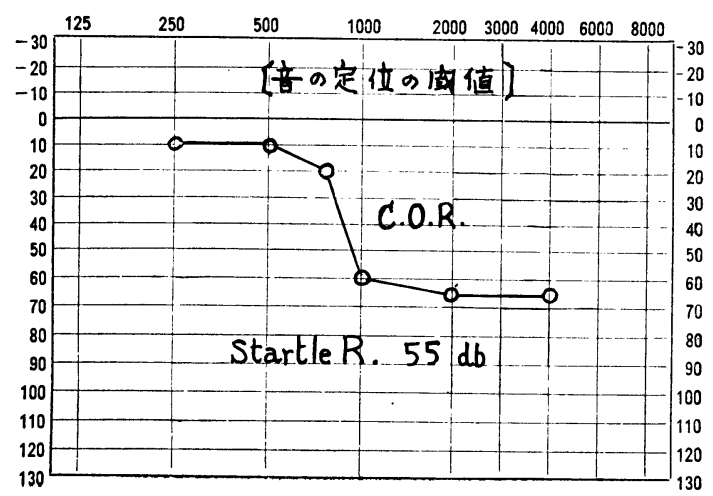

現病歴： 2 才頃ウンマ，マンマをいったが，てとばの 発達が悪く小学校 1 年頃迄は何をいっているかわからな かった。こちらのいう事は殆ど理解出来ない(手まねを まじえれば出来る) が童謡は 3 才頃より上手にメロディ 一を口すさむ. 小学校 1 年頃より難聴があるのではない かと思われた. 現在読字, 書字は普通に出来るが他人の ことばはしばしばきき返さ双と理解出来ない。

検査所見: 昭 37 年 6 月, 8 月の純音聴力検査では正常 音の定位, 音の意味の了解 (楽器音, 動物のなき声の弁 別）の障害あり精神意堂疑う。しかし純音聴力検査を繰 返し行なうと閾值が極めて不安定で反応の確実出ると てろは図 1 亿示すでとく $1000 \mathrm{cps}$ で 70db 以上であるが この闌値至身も絶えず変動している。語音㯖力も悪く, ての值も時と共に变る（図3）. CPRでは $1000 \mathrm{cps}$ 以上で は 500 cps に比して閾値の上昇が著しい（図1)。乙れら の所見は中枢性聴覚障害の存在を推測せしめるが，CPR の所見からすると本例では聴觉障害が聴覚等の相当下部 にも存在することになり, 队目性難聴を否定し得ない。
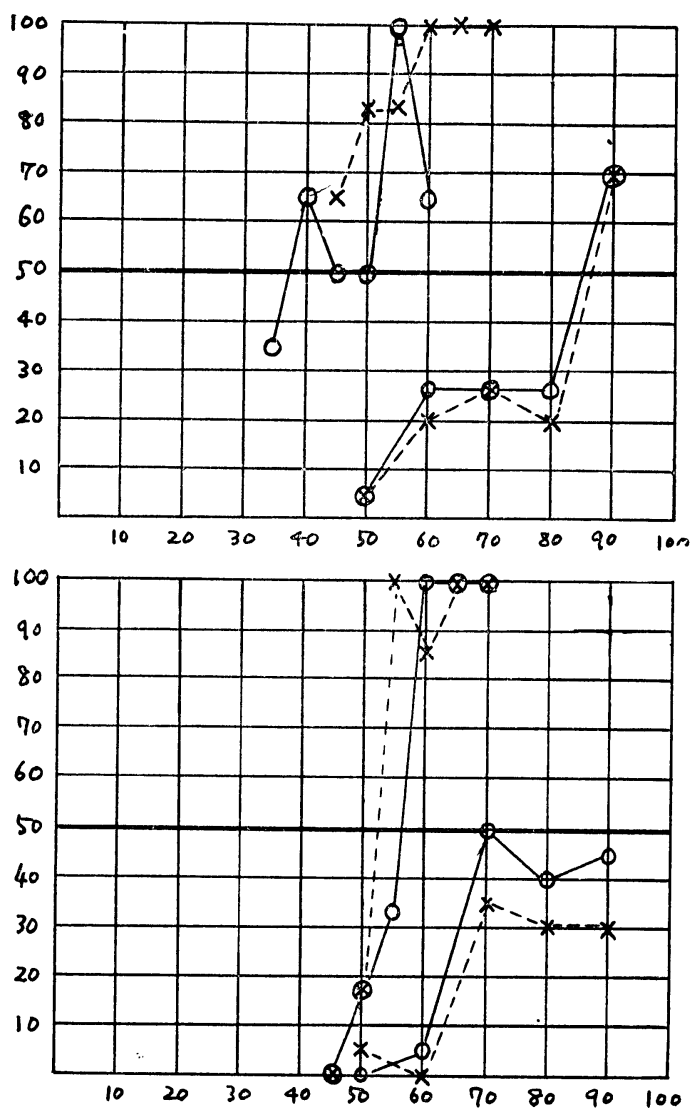
14. 原因不明の構音障害に対する

\section{Speech Training の 1 症例}

堀口信夫 ○飯沼正子

（東大分院）

我々は, ある原因不明の構音障害患者について, 凡そ 5カ月にわたり Speech Training 它実施した記録をたど り，一症例として経過を報告した。

患 者：○尾○耶，11才，女子.

初嗙日：昭和36年11月24日.

既往歴: 昭和 33 年 1 月 mumps.

現症歴：炤和 34 年 1 月頃舌がもつれ発語がはっきりし なくなったととに気付く，その後同年 8 月頃より不明瞭 さは著明かつ増悪する。

神経科所見：IQ：82（9才6力月）

その他神経科的諸検査の結果多少の所見はあったが，特 に神経病的診断は不朾のまま。

耳鼻科所見：発語明瞭度 $66 \%$

全般に発語時舌が前に出すぎるが，殊にか行；さ行；た 行；ざ行；だ行；音にひどい。

舌の動きは上下・前後・左右何れも困難. 発声はか細く ふるえ声, 常に流涎茥だしい.

練習方法：ガムを咀みつつ, 極く簡単な朗読と会話か らはじめ，次第に他の練㥜も加えて行なった。

たとえば 1カ月半後一紙風船の blwing 小〜大

2 力月後一舌の左右運動

2 力月半後一舌の上下運動

3カ月後一ストロー,肺活量計苍使用して呼吸 気の練習.

練習時間を最初の 1 日15分から次第に $30^{\prime} \sim 60^{\prime}$ と増して 毎日 1 回行なった.

経過観察 :

1 力月半後一声がやや大きく，上ずった调子が減る内 容ははっきりと分りかねるが，自発的に話題を転じてよ くしゃべりまくる.

2 力月半後一舌尖が左口角にもかろうじてつく．ての 頃会話中に下顎の動きが伴なって来た. 話の内容も, 他 人が聴いて分り易くなった，始めて自ら歌を唄うが，声 域は狭く $2 \sim 3$ 度程度。

3 カ月後一舌尖が煩部にもつく. 電話で話しても相手
にはっきり通じるようになった。最高肺活量は600程度。

4 力月後一声域は 7 度位に広万がる，話しながら盛ん に舌打ちをする。とれはてれ迄不可能なととだった．肺 活量800〜900にまで上達する.

4 力月半後一ガムを舌尖で破裂させられる. 文章の phrase 究とばしたり, 不明瞭さが少なくなる。 発踣明膫度 94〜100\%となる。但し，い列音，きょう しょ等の拗音が，完全でない。

人に指示されたり, 愦り觉指摘されるとと極めて嫌 うため, Guzmarn 最初のゾンデ法を適用しかけたが, 直ちにガム赏体用して Chewing method に切り換え, 朗読の際にも出来る限り途中で指摘したり, 注意したり すること避け，患者にとってでく自然の状態の中で Training 党行なうよう特に心掛けた。

最初の半月程の間は澌間に刘してかぶり苍振ったり, いや」といって厑定する位で, 絶えず周国の様子觉気に し, 腰も落付加ぬまま15分閴の練習もようやくの態であ った，終日ガムを勗むととをすすめて流涎も少なくなり 1 力月半後, 多少声も大きく, Therapist とも染んだ頃 にはまるで人が变ったように，不自由な舌をあやつりな がらも，自発的に話題学転じてとめどなくしゃべりまく るようになった。この頃から食䭒も固形物が摂れるよう になった。

言葉の状態はしかし，日によってむらがあり一進一退 の末上述の如き経過虎ふんだ次第である。年少ながら人 問関係問の微妙な霍团気に対する感受性が強く, 反応も 敏感小ため気分の良し覀しに依って言葉の調子もそれに 影響されることが多かった。徒って常に明るくひきたた せる配虑と忍耐壱もちながら Training をすすめる必要 があった。

結語: 我々は一見器質的咨患とも思われる原因不明の 構音障害患者に対し， 5 カ月にわたり Speech Training 苍行なった結果言語機能に良い効果をもたらしたので報 告した。 
15. 舌半側切除後の言語について

後藤敏郎 ○江口実美

（長崎大耳鼻咽喉科）

舌癌の手術では, 術後の言語障害が重要な問題となる 演者は長崎大学耳鼻咽喉科において, 舌半側切除術をう けたもののうちで, 検査の出来た10例について, 舌根を 含んで切除したものと, 舌根を残したものとの 2 群に分 って, 術後の音声を観察した. 各症例の術後年数は 1 力 月のものから，10年を経たものにわたっている.

発語明瞭一検查では，明瞭度か $90 \%$ を越えるもの 1 例 もあるが， 60\%以下を示すものは認められない。

構音器官運動機能検査では, 舌の運動はすべて障害さ れているが, 口唇及び下顎の運動, 及び呼吸運動には障 害はない. 口蓋, 咽頭の機能は約半数例において障害さ れている。

ソナグラムでは, 母音のフォルマントは第三フォルマ ントの低下を認めるが，各症例において大差を梕めない 子音では, 子音波は存在が不明瞭か, 非常に弱く, 低周 波域にあり，又，移行部は長いか，不明瞭である。

以上の各検査からいえることは, 術後の言語障害は, 舌根の有無によって著しい影響をうけないてとであり， 関連筋肉の損傷. 縫合固定, 術後年数, 職業等に影響さ れることである.
16. Dysphonia Spastica $の 4$ 例

\author{
○東川清彦 長尾暢三 \\ (凧山大)
}

第 1 例は56才男子のセールスマン, 第 $2 \cdot 3 \cdot 4$ 例は 20 才台女子の独身で, 何れもが電話交換手であった.

ての 4 人に対して種々調べてみると, Dysphonia Spastica となる明らかな誘因を見出すととができた.

これに対して, 忍耐強く治療すると, 一時的には軽快 するが，少し油断をすると再び悪化するという傾向を認 め, 完全に治癒させるととは仲々むずかしいと云うとと 知った。 
IV 群

各種の音声障害 座長 林 義 雄 博 土 (東洋病院長)
17. 吃音者の症例研究（第 1 報）

\section{荻野利之}

（花沢研究班）

私達は, 本医学会に於いて数回に亘り, 主として心理 学的及び身体的, 生理学的に吃音の本態関する研究を 発表したが，今回は現在，私達の行ないつつある症例研 究から, 特に心理学的, 精神医学的に試みたアプローチ から見いだしたある類型について報告し，その治瘭経過 予後等についても言及してみた。

(類 型)

A型（一級吃り 4 7才, 子供の初期吃.)

1 型 内言語と言葉の均衡破裂

2 型 情緒と言葉, 子供言葉.

3 型 思考の未熟と発表能力と.

4 型 吃りの口真似.

B型 (一級吃り以外の吃り)

I 型 殆んど純粋に吃音のみが動機として二級吃り苍 形成したもの.

II型 精神的な事件が動機, 又は契機となって二級吃 を形成したもの。

而型 内因（性格，ノイローゼ）が吃を固定し，結び ついたもの.

18. 機能性, 声障害について

$$
\text { 中川泰涁 }
$$

(東大神経科)

広瀬 肇 小林武夫 岡村正美 (東 大)

器質的に発声器官に異常を発見しえない発声障害二十 数例を精神医学的に検討してみた。

ケイレン性とマヒ性とに音声学上区別しているが，両 者の精神的原因, 性格, 職業之の関係, 発声障害の精神 的メカニズム等にも明らかな差異が認められた。
マヒ性発声障害は原始的な心因反応と考光られ、ヒ性 発声障害はより高度で複雑な精神的メカニズムによって 発生するものと考光られる。

19. 脳性小巟麻瘏の発語障碍

$$
\text { について（第 } 2 \text { 報） }
$$

$$
\begin{aligned}
& \text { 広户幾一郎 ○立石 厚 矢野鉄郎 } \\
& \text { (久留米大) }
\end{aligned}
$$

日野紀典 本間一弘

$$
\text { (ゆ5かり学園) }
$$

我々は昨年の本学会に於いて脳性小児麻瘦児(以下C $\mathrm{P}$ 巟之略す)の，全身所見，肺活量，レ線の 2 重撮影に 上る横隔膜運動等觉検査し, 之等の成績と発語障碍との 関係について述べた。

今回怯 C.P. 児に於ける人体微細振動 (Minor Tremor) について観察を武みた。

Minor Tremor (以下MTと略す) の誘導記録には口 ッシエル塩 pick up を使用した。 之は直径 $3.0 \mathrm{~cm}$, 厚
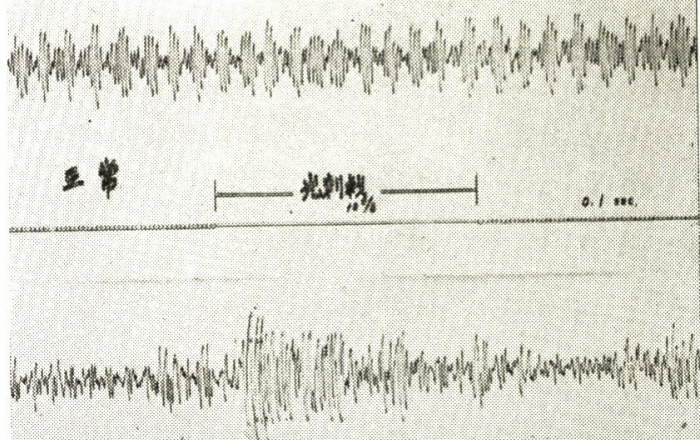

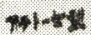

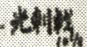
a.t $n$.

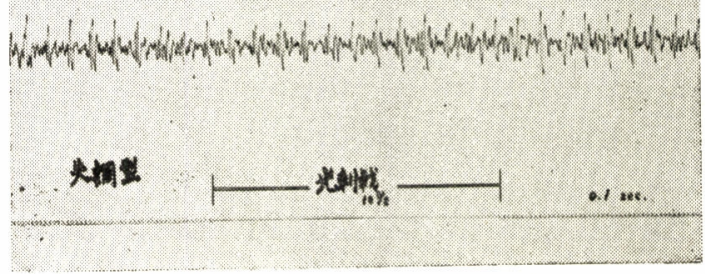


さ $1.5 \mathrm{~cm}$, 重さ $15 \mathrm{gr}$ である。との pick up の装置部位, 即ち $\mathrm{MT}$ の誘導部位は一般に丹指球, 又は敏感な上眼一 などが用いられるが，C. P. 垐で最も発語障碍が多く， 然も高度なアテトーセ型では, 全身の不随意運動がある 為に之等の部位加らの誘導は困難で, 且つ成績の不正破 を来すので比較的安定している胎の左右約 $3 \mathrm{~cm}$ の直腹行 部に pick up 觉固定し，ここからMT芷誘導記録した。

C. P. 児を暗くした室のベット上に仰臥させて，安溯 になったとと觉MTの波形により確かめ，ストロボスコ ープによる $10 \mathrm{c} / \mathrm{s}$ の閃光刺战， $500 \mathrm{c} / \mathrm{s} ， 90 \mathrm{db}$ の音刺战の 他化 5 母音の発声を行なわしも, 之等 3 者によるMTの 変化を記録したが，図 I は例として光刺㦸尤るるMTの 変化を示している. 痙直型についても勿諭行絷った。

次にMTの周波数分析壱行なうと図 2 の如くなる。即 ち $(4 \sim 8 \mathrm{c} / \mathrm{s}) \alpha(8 \sim 13 \mathrm{c} / \mathrm{s}) \beta(13 \sim 20 \mathrm{c} / \mathrm{s})$ の 3 周波

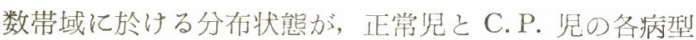
間に著明な差があるの敩認める。同樣に音刺㦸, 発声に よるMTの变化も種々の方向加ら維察した。

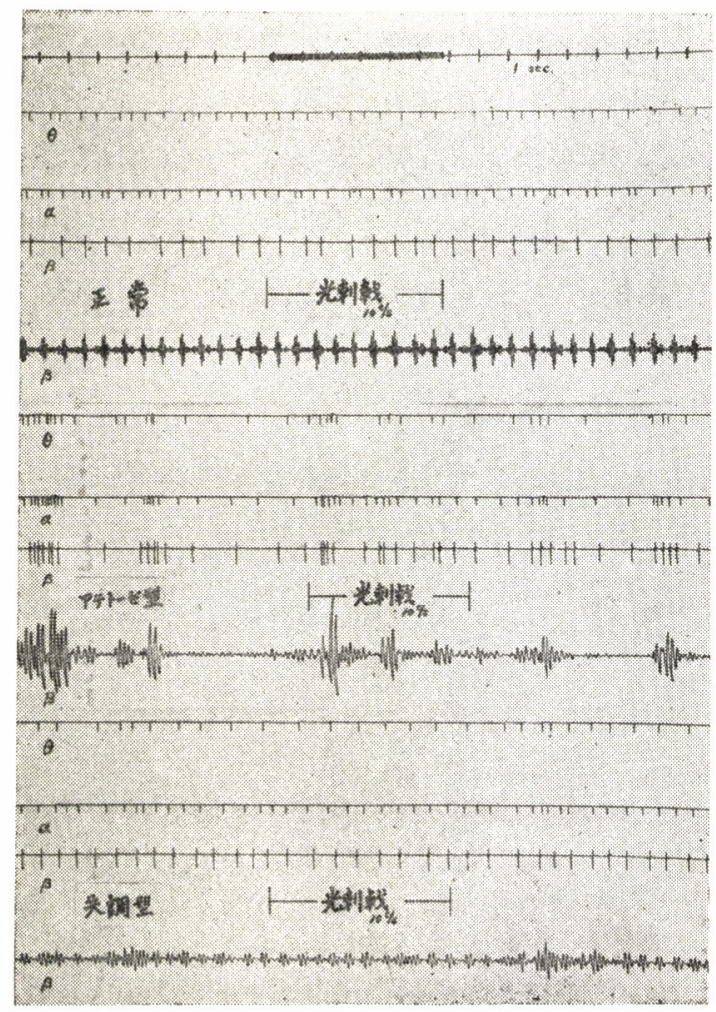

20. 小巟の Receptive Aphasia 之襲の鑑別

-Diagnoshic Teaching の重要性一

\author{
○清水 弘 \\ (京都府立医大) \\ 山口薩記 \\ （京都言語障害相談所）
}

Communicah'on disorder 飞刘卞る種々の検查方法, 殊に小別聴力検查法力溌達した今日, 中枢性言語障害と 犝筑の鑑別は容易になった様に見党るにも拘らず，相手が 小さい子供の場合此の方面のエキスパートですから初診 時に確定的な診断のつけられない場合が決して少なくな い. 研究対象である京都万弓学校の中にも驡児として襲 教用堂受けていながら，しかも知能正常で，他何何ら心 理的問題离持たないにも拘らず一向口話法省修得せず， 従って言語発達の見ら机ない生徒がいるとと, 及び演者 等の䠛牀経駼加らも。所謂 Aphasic deaf child と呼ば れる dual handicaps の你在范信じ，聴力障害のみが言

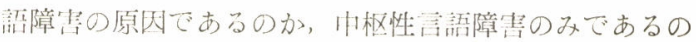
か, 或は雨者が合㴊しているのか不明の眭は, Diagnostic teaching 范直ちに始めることが最も有力な武舆であるこ 之竞唱いた。之は早期教育方检の決定にも重要である。 この原理は次の一般的経験的法則加ら来ている。

(1) Aphasoid/(との中には Auditory agnosia 或は

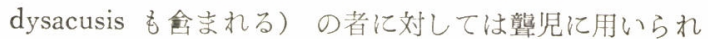
る訓練方法方成功しない。

（2）聴力障害のみで他伦何の障害も持たない子供は大 体3才位点でに視覚党通じて何らかの形で vesbal-symbolic learning 党示高.

(3) 聴力障害, 知能障害, Psychosocial な問題で言語 遟滞を来している者は a phasia 亿含まれない。

(4) 言語荧要しない Performance 浪正常である。

(5) Aphasoid はケースによって音に対する反応の仕 方 (升则觉含めて) がまちまちである。

(6) CNS の障害の存在を疑わしめる病歴と Multiple handicaps 苍持った子供は少なくない。

（7）以上の事柄の大部分は初崄時の検查よりも，巧み な Diagnosh'c teaching によって明確にされるものであ る. 


\section{$\mathrm{V}$ 群}

基礎的研究 (3)

座長 片 桐 主 一

(東北大教授)

21. 語音発声時における棈音運動の

筋電図学的研究

広戸幾一郎 平野 実 進 武幹

矢野鉄郎 豊住頼一 ○岩下明弘 (久留米大)

語音が発せられるメカニスムの解明にはレ線映画によ る観察, 附属共鳴管腔内圧の消長の測定, 音声の分析等 種々の方法があるが, 我々は構音に関与する諸符の筋電 図と音声とを同時に記録し, 之等の筋の作働様式を研究 した.

口蓋帆挙筋は通常発語の $250 \sim 400 \mathrm{msec}$ 前より筋収縮 を開始するが，ての時間は語音により，又起声法てより 差がある．筋放電の強さは語音により差があり，母音で は〔i]で強く〔a]で弱くその他は両者の中間である

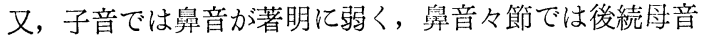
においても収縮は弱い。

尚, 現在口輪筋等についても研究中であるので, その 詳細は講演の際に述べる予定.

\section{2. 構音機構の発育に関するレ線的} 研究（第 1 報）

柳原尚明 ○東 文生 (京 大)

正常の語音構音機構に関しては, 古くより多くの研究 が行なわれ種々の知見が得られているが, 構音器官及び その運動が年令と共にどの樣に発達しているかに関する 研究は少ない.

我々は喉頭・上中下咽頭腔・口腔の側面像を, 高圧レ 線遠距離瞬時撮影により一フィルム上に明瞭な写真とし て描き出し, 構音機構の発育について若干の知見を加え 得たので報告した。

今回は, 5 才より15才に及ぶ各年令屏について, 安静 呼吸時及び 5 母音話声位単音節発声時の構音器官の側面
レ線像を詳細に検討し，次の如き結果を得た。

1. 安静呼吸時の構音器官の年令的発育.

(a) 構音器官の前後径, 即ち Spina nasalis anterion 上り上咽頭後壁迄の距離及び上咽頭腔の深さは, 年令と 共増大の傾向を示すがその測定值の変動が大である. 硬口蓋の長さの発育は年令と相関関係がある。

（b）軟口蓋の長さ及びその正中矢状面の面積を，成人 の場合を基準値にとって比較する時, 発育の程度は, 5 -8才，9-12才，13-15才，の3つの年令圈では差が認 められる. 即ち，5-8才群では漸次増大 9-12才群では 增大を殆んど認めず，13一15才群で急に増大する。

2. 母音発声時の構音器官の発育

（a）附属管腔の形態，特に軟口蓋の形態は，年令的に やゃその態度を異にする。例えば上咽頭閉鎖は，幼児で は不完全の場合が多く，ア発声時には，上咽頭は閉鎖せ ず，鼻腔と交通していることが多い。

(c) 母音別に見て発声時の軟口蓋の正中矢状面での面 積及び長さは，変動しない。乙の現象は各年令層を通じ て一定している.

(c) 母音発声時の軟口蓋の正中矢状面での面積及び長 さの絶対值は $12-13$ 才を境に，急激に増大する。

（d）軟口蓋の発声時正中矢状面面積と, 安静呼吸時の 面積の比, 即ち発声時の軟口蓋の拡大率は，12才を境と して急激に増大する。

（e）軟口蓋の発声時の高さは，成人になると大体，イ ウエオアの順に分化して来るが，小児の場合，ての分化 は不明膫の傾向がある。

3. 母音発声時の口腔・咽頭腔の形態

(b) 舌・口蓋間の母音発声時の狭窄部の位置は, 年令 的にははっきりとした差を認めない. 即ちイエが前方， ウが中間，アオが後方に狭窄部を作るが，工は変動が多 い.

(b) 母音発声時の附凮管腔にわける狭窟部の正中矢状 面での幅は，成人と小児で比較すると，その絶対值には 著名な差が認められない。

喉頭の年令的な発育は，比較的よく研究されているが 構音器官の年令的な発育は, その有する要因の複雑なた め, 今日迄に得られている知見は乏しい. 以上の結果か ら見ると構音機構の発育にも，年令的な特異性があるて とが類推される. 今後回を追って，それらの点について 報告するつもりである。 
23. 内喉頭筋の作働様式に関する 筇電図学的研究

厷戸幾一郎 平野 実 豊住頼一 ○進 武幹 （久留米大）

内搌頭筋が呼吸, 䓙下, および発声に際して, どのよ うに作動するかを筋電図により研究し, 若干の知見を得 たので報告する。

筋電図は総て経皮的に電極を插入して誘導記録した。 又, 語音発声の際には, 音声を同時録音し, sonagram に描画して先行波, 子音波等の細部に迄わたり筋電図と 対比検討した. その成績を概括的に述べると。

[I] 呼财時

(1)前筋：通常筋放電が見られ吸息時の方が呼息時上り も放電は著明である。

(2)側筋, 内筋, 横筋: 筋放電は呼息時僅かに認められ 吸息時には極めて弱いか消失している.

(3)後筋: 吸息時に強い放電を認め, 呼息時にも弱い放 電がみられる。

[II] 䳕 下 時

(1)前筋：筋放電は䓵下の終りにみられる。

(2)側筋, 内筋, 横筋：強い収縮がみられる.

(3)後筋：筋放電を通常みない.

[III] 発 声 時

(1)前筋: 発声の初期強い放電があり, 後は弱くなる ものと, 殁んど発声中強い放電を持続するものとある.

(2)側筋, 内筋, 横筋: 強い筋放電をみる.

(3)後筋：極めて弱い筋放電をみるか全く放電をみない (IV) 語音発声時

(1)前筋, 側筋, 内筋は発声飞先立って筋収縮を起す. 但 し無声子音々節では, 無声子音波は筋放電出現の前に発 せられる場合もある.しかし後続母音は常に筋収縮開始 後一定時間を経て発せられている．乙の発声準備状態と もいうべき時間は筋により語音により又, 起声法により 若干の差異を認める.

(2)後筋は発声一定時間前に筋放電消失又は微弱化する その状態は語音, 起声法により差異を認める.

(3)二語音連続発声の場合, 語音の組合せにより種々の 作働梯式をみる. 母音十母音, 母音十有声子音では, 即
ち後に有声音々節がくる時は, 側筋, 内筋, 横筋にほぼ 同一の収縮を持続し，後筋は終始弛緩している．前筋は 音節の変化に関係なく放電が持続する場合と音の頭毎に 強い放電がみられる場合とがある，後に無声子音々節が くる場合は, 側筋, 内筋, 横筋は筋放電の一時的消失又 は減弱を, 後筋は一時的筋放電の出現をみる. 前筋は先 そのべた二つの型の何れかをとる. 
24. 語音発声時の附属管腔内圧に

関する実験的研究

広戸幾一郎 立石 厚 平野 実
○矢野鉄郎 進 武幹 矢武良規
富田英寿
$\begin{gathered}\text { 岩下明弘 宮城 平 } \\ \text { (久留米大) }\end{gathered}$

構音機構を解明する一方法として, 語音発声時の鼻内 圧, 構音帯圧, および声門下圧の変動を測定し, 若干の 知見を得たので報告する。

鼻内圧, 構音带圧は差圧計, 声門下圧は電気血圧計を 用いて測定, その経時的変動を音声と共に電磁オッシロ 亿記録描画し，闹時に録音した音声の Sonagram と対 比しつつ, 細部にわたって検討した.

実験成績の概略は下記の通りである.

(I) 鼻 内 圧

(1)母音, 有声子音及び無声子音音節: 一般に圧上昇は 認められない。

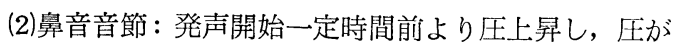
一定に達すると発声が開始される, 圧は上昇を続け, 鮙 子音部の終りで最高に達し, 以後急激に下降する. その 時の圧は個人により, 又後続母音により異なり, 2〜24 $\mathrm{mmH}_{2} \mathrm{O}$ の範囲にわたる.

(II) 構音帯圧

(1)母音：母音の構音帯とは, 主として舌の運動により 作られる附属管腔内の狭窄部とする。圧上昇は殆んど認 められない。

(2)鼻音音節：圧上昇は殆んぞ認められない。

(3)有声子音音節 :

(a)破裂音: 発声と同時に圧上昇がみられ，先行波の終 りで，圧最大となり，子音波に入ると同時に圧は急激に 下降し始める.

(b)摩擦音: 発声と同時に圧上昇し始め, 子音波のほぼ 終りで最大となり, 移行部へ入ると急激に下降する。

(4)無声子音音節 :

(a)破裂音: 発声開始一定時間前汃ら圧は上昇し始め, 発声直前に最高となり, 発声開始と同時に圧は急に下降 する.

(b)摩擦音：やはり発声開始一定時間前より圧上昇開始 するが, 圧が一定に達すると子音波の発声が開始される
その後も圧は子音波中で上昇を続け, 子音波の終り近く で最高に達し, 以後下降する，破裂音，摩擦音を問わず 同一人では最高圧は有声子音より無声音子の方が大であ る.

（III）声門下圧

(1)全音節共に圧は発声に先立って上昇する.

(2)母音, 鼻音及び有声子音々節では圧は滑かな曲線を 描いて変動する.

(3)無声子音々節中，破裂音は子音波の終りで，摩擦音 は子音波の始りと終りで一時的にわずかの圧下降をみる 即ち圧曲線汇段がつく。

(4)最高圧は個人差が大で， $25 \sim 110 \mathrm{mmH}_{2} \mathrm{O}$ にわたる が, 同一人が同一の高さ及び大きさで発声する時は, 語 音間の差は殆んぞ認められない. 


\section{VI 群}

異常音声の観察 (1) 座長 高 原 滋 夫 (岡大教授)

25. 東大分院における音声言語 障害診療の統計的考察

堀口信夫 ○飯沼正子 (東大分院)

昭和34年 4 月から 37 年 8 月末まで汇当科苍訪れた音声 言語障害者 538 例につい統計的考察をした。

音声・言語別，性別にみると音声では，女性が若干上 回り, 言語では男性と女性の比はほぼ 2 刘 1 の割合を呈 した. (第 1 表)

主な疾患別には, 音声では喉頭炎が音声患者 339 例の うち $67.4 \%$. 次いで反趣神経麻瘦, 学童嗄声,その他の順 に多く, 言語では口蓋破裂, 構音障害, 言語逢滞, 吃, その他の順に多くみられた。（第 2 表 $\mathrm{a} ; \mathrm{b}$ )

262例の喉頭炎のうち，いわゆる職業性音声障㫪は58例 で22. $1 \%$. 年令的に男女共 20 才前後住集中され，女性は 男性の約 2 倍に達した. 職業別には洋楽專攻が58例のう $572 \%$. 次いで教師, 邦楽(長唄), 新㥵俳優, セールス マン, 電話交換手, バス車掌, 落語家に分けられた. 洋 楽の声種別では Mezo; Soprano; Tenor に多く Alto；

Bass に1例もみられなかった。

構音障害39例のうちサ行音障害が最も多く, ラ行, 力 行音障害がそれに次いだが，例数は少なくとも，原因不 明の構音障害があり，それは実際に Speech Therapy 苍 行なう場合に多くの問題点を供し, Therapist にとって も辛苦を玩味させられた。

第 1 表 音声・言語別，性別統計

\begin{tabular}{cccc} 
& 男 & 女 & 計 \\
\cline { 2 - 4 } 音声障害 & 176 例 & 213 例 & 389 例 \\
\hline 言語障害 & 92 例 & 57例 & 149 例 \\
\hline & & & (総計) \\
\hline
\end{tabular}

第 2 表 主な疾患別, 性別統計

(a) 音声障害……

\begin{tabular}{|c|c|c|c|}
\hline & 男 & 女 & 計 \\
\hline 反廸神経麻䔉 & 22 & 15 & 37 \\
\hline $\begin{array}{l}\text { 喉頭 炎 } \\
\left\{\begin{array}{l}\text { 急 性 } \\
\text { 慢 性 } \\
\text { 悪急性 }\end{array}\right.\end{array}$ & $\begin{array}{l}106(18) \\
34(4) \\
67(14) \\
5\end{array}$ & $\begin{array}{l}156(40) \\
55(12) \\
97(27) \\
4(1)\end{array}$ & $\begin{array}{r}262(58) \\
89(16) \\
114(41) \\
9(1)\end{array}$ \\
\hline 変声障害 & 4 & 5 & 9 \\
\hline 学童嗄声 & 21 & 5 & 26 \\
\hline その他 & $\left.{ }^{23}\right)$ 内 & $\begin{array}{l}32 \\
\text { 大職業性 }\end{array}$ & $\begin{array}{c}75 \\
\text { 障害者数 }\end{array}$ \\
\hline
\end{tabular}

(b) 言語障害……

\begin{tabular}{lccc} 
& 男 & 女 & 計 \\
\cline { 2 - 4 } 口蓋破裂 & 20 & 28 & 48 \\
\hline 構音障害 & 29 & 10 & 39 \\
\hline 吃 & 10 & 4 & 14
\end{tabular}

\section{言語遅滞}

\begin{tabular}{|c|c|c|c|}
\hline (犝哑 & 12 & 4 & 16 \\
\hline 聴殐 & 4 & 4 & 8 \\
\hline 難聴 & 6 & 3 & 9 \\
\hline その他 & 11 & 4 & 15 \\
\hline
\end{tabular}

京都府立万う学校生徒を対象としてあらゆる角度から ，彼等の言語発達の研究を行なっているが，今回はろう 児の病歴の一端を紹介し, 単音, 単語文章の発語明瞭度 成績 と 1)残存聴覚機能 2)読唇能力 3)教育開始期 4)教育期間 5)年令 6)聴力損失時期 7)声質との関係 及び 8)単音, 単語, 文章発語明瞭度相互の関連性につ 
いて統計的考察を行なった結果を報告した。

被検者はろう学校生徒の中, 低知能指数を有する者等 心理学的問題を有しない生徒 100 名を対象とした. 又と れらの対象として正常聴力者 15 名について発䛇明膫度検 查を行なった。明膫度検查谁篻音, 単䛇文章について行 ない, 被検者の声をテープコーダーに防音室にて録省 し, 之を自由音場で再生し, 検者 7 名に聴取させ, その 中最高最低值を除いた中間値を有する 5 名の百分率の平 均值をもって発語明瞭度とした，淌文管には質間形式の リストを用いた，読唇能力検査は文章及び単語について 調べ, 前者には検者か櫍問文を述べ之に答壳させ, 後者 は検者が指定した玩具を取り出させる方法を用いた，又 病歴は特に母親に来院させ, 清水が考案した検查表に占 り詳細な問彭をした。

その成續より, 単音, 単語及び文章相自䦓には明膫度 の上に一定の関連性を認めるが, 必ずしも平行的な関係 は見られない. 又発語明膫度と残存辐覚機能, 読唇能力 聴力損失時期及び声質の間にも深い関係のある事などを 需かにした。

\section{7. 言語障害巟の原因}

\section{鈴木篤郎 ○田中美郷 前沢恵子} (信大)

昭和36年 9 月より 37 年 8 月迄の間に我々の幼児聴力相 談室で扱った言語障害児 127 名について聴力・精神発達 検查を主体に原因の検索を行なったみた。言語障害児は 難聴や精神発達遅滞を伴なう場合が多く, Border line のものも含めると約76\%になる. 性別では女よりも男に 多く，ての差は難聴のないものの方に著明であった，両 親に血族結婚がある場合は殆ど難聴又はろらの形で出現 し, 聴力・精神発達正常で言語障害だけの群には血緣に 言語障害を持つ場合が多かった. 又体の妊娠中に重要 疾患を経過している場合が意外に多く（重症つわり，黄 逭, 妊娠中毒症, 風疮々の他 $35.4 \%$ ), 特に精神発達遅滞 児の場合には51\%に達し，てれに次ぐのが言語障害のみ の群 $29 \%$ であった. 仮死産又はチアノーゼは全体の $20.2 \%$ 亿恝められたが, やはり精神発達遅滞児の群が最
も多くをしめ $(25.0 \%)$ ，言語障害のみの群がてれに次い で多かった (18.5\%). 又出産時体重3. $5 \mathrm{~kg}$ 以上のものは 精神発達遅滞児群だけにみられた. 左ききは精神発達遅 洲を伴なわない言語障害のみの群に多く $(22.5 \%)$, きき

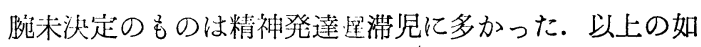
く難聽のない群では精神発達遅㴖のあるものと言語障害 のみの群の間には家族歴, 吥往歴の上で可成り共通点が 見出される.

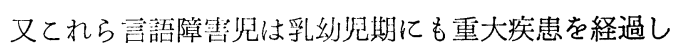
ている場合が多く,大した聅病もなく経過したものは127 例中 27 例 $(21 \%)$ にすぎなかった。

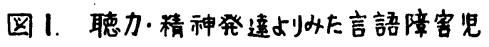
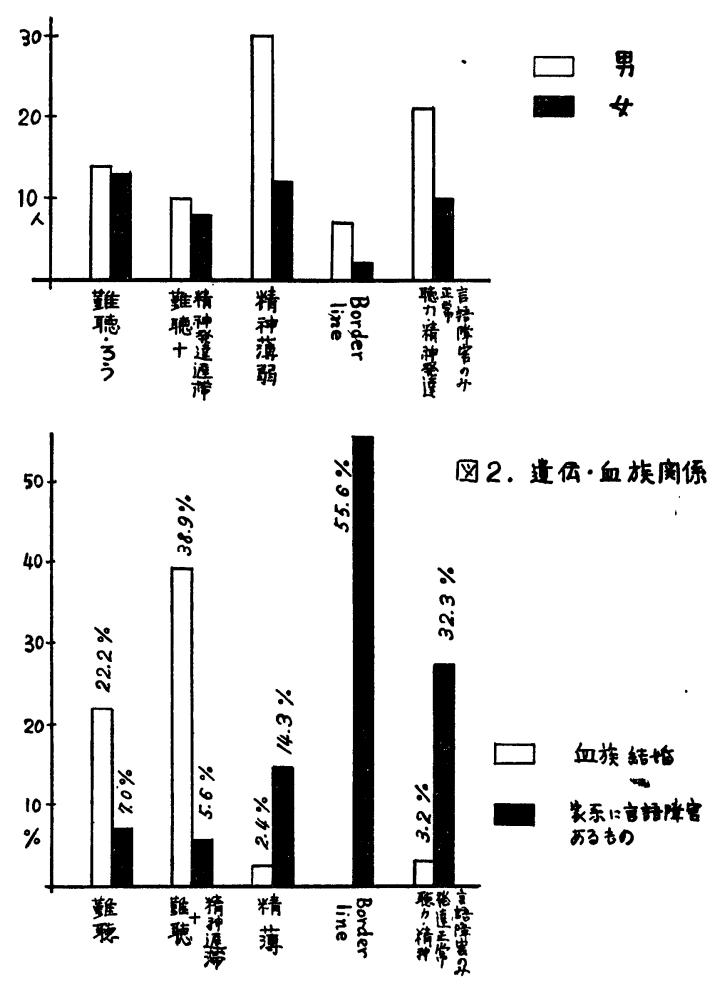
28. 言語の発達言

一言語発過遲滞児について一

河村正三 ○野口憲道

(順天堂大)

茂木しげ子

(東 大)

正常発達児と言語発達遅滞児の三症例とを比較検討し たので発表する.

ての言語発達遅滞児は, 聽力は良く, 知能も正常であ

り, 家族歴, 既往疾患も特記すべき程のものはない, た だ第 1 例は分婏時難産であり, 仮死の状態で出産した.
結 語

幼児語が尚混在している(正常児の場合は 2 年にて消失) 二語文使用開始遅延 (正常児の場合は有意語の開始より 大体7〜8カ月後に出現している）等.

言語発達その一「正常児」の数值より,すべての点で遅 延している.が言語発達は正常児の過程と大体一致して 発達して行く.

又, 耳鼻咽喉局所所見も異常はない.

(尚三例とも，現在経過観察中である.)

\begin{tabular}{|c|c|c|c|}
\hline & 第 I 例 & 第 II 例 & 第 III 例 \\
\hline 生 年 月 日 & S 34.11 .11 & S 34.6 .5 & $\mathrm{~S} 34.5 .11$ \\
\hline 片言の始った年令 & 不詳 & 1 年 6 力月 & 1 年 \\
\hline 有意語 開始年令 & 1 年 6 力月 & 不詳 & \\
\hline 言 語 の 增 加 & 2 年 7 カ月 & 3 年 & 3 年 \\
\hline 二語文使用開始年令 & 2 年 7 力月 & 3 年 & 2 年 10 力月 \\
\hline 歌の始った年令 & 2 年 4 力月 & 2 年 11 カ月 & 3 年 \\
\hline 幼児 語消 失年 令 & 現在も幼巟語混在 & 左 & 同 \\
\hline
\end{tabular}

29. 機能性発声障害の polygraph

○高橋 宏 伊藤祐台

（国立精神衛生研究所）

ピッチ・レコーダーを用いて. 会話音声の周波数分析 波と強さの曲線を連続的に記録し, それに加光て, 呼吸 曲線, 心電図, 心搏曲線 (Cardiotachogram), G. S. R を同時的に連続記録する装置によって，機能性発声障害 者に対する精神医学的面接にわける発声時の身体状態と 発言との関連を検查した。

患者はいずれも耳鼻咽喉科学的には所見がなく、また は治療が奏効せず, 精神医学的診療に回されたものであ る.

検查の面接内容は, 一般的面接, 投射法性格検查（絵 画統覚検査) などを含み約分 30 間連続記録したものであ り，同時にテープ録音されている. 発声障害をもたない 他の被検者の記録でも，各身体現象は相互に関連しつつ 集中的な変動を示し易く，その籄所の発言内容を見ると
被検者の精神病理学的異常体験や，心理葛藤にふれたた ぬ，感情的冷静を保ちがたい場合と推察できるものであ るととが多い.

痤戀性発声障害者の場合も, 同時記録の変動が患者の 感情的動摇およびそれに伴なう発言と関連して見られる ことには変りない。しかしてれらの患者に特に著しいこ との 1 つは, 時折発声時に呼吸が極めて淺くなっている ことである. 患者は時に10秒ほども，息を補なうことな く話しつづけようとする．そしててのときに多く発声の 障害を伴なっている. また同時に心搏曲線や GSR の上 にも変動を伴なっているてとが多い，そして発言のない ときには，むしろ呼吸の規則性は恢復している.

てれに反して, 他の被検查の場合には, 心理学緊張に よる呼吸の停止した状態は，むしろ発言のないときに見 られることが多く，発言が始ると呼吸は此較的規則性を 恢復する.

てれは痤攀性発声障害という状態の成立機制に関連の

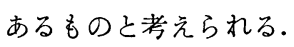


VII 群 （29〜32）

異常音声の観察（2）座長 大藤 敏 三 (日医大教授)

30. 吃する音と舌口蓋筋との

関係について

野中肖人

(野中研究所)

吃する音は大体に於て限定されていて, 行, 力行に 吃する者が多いが，中にも別表の如くカと夕音仡吃する 者が最も多い. 又子音仡吃する音は, アの母音がつく音 に多く吃する。

夕とカ音が何故に斯くも障害を受くるか検討してみる 之, 胸壁の挙上運動か障害され斜角筋の作用が不全に宿 いると，吸息の場合に舌骨の下制筋が緊張を起し，舌骨 が下方に率引されると声門は開き, 口蓋帆, 舌等の発声 器が活骨によってその動作を星制される結果, 発声の場 合には舌骨の牽制力に対抗するだけの緊張力兌, 発声器 に加えなければ発声は不可能である。それでその舌骨の 率制力に対抗するために，努力によって胸壁を緊迫し胸 腔内の息を圧縮して，強圧の息を口咽腔内に圧送するこ とによって, 発声器の緊張を增強させ, 口蓋帆の挙上並 に舌の調音動作等を図らんとするものである.

しかしながら，夕音は第 1 図，力音は第 2 図化示す如 く, その父音の調音動作觉起すと，その舌が強く毉張を 起せば舌口蓋筋も自然緊張を受くるために，第 3 図に示 す如く舌口蓋弓の牽引によって, 口蓋帆挙筋の作用注影 響を及ぼし, 後鼻孔の遮断に障害を起す結果, タ, 力行 音に吃する者が多く, 殊にアの母音は口蓋帆を広く伸張 して発する母音であるから，父音と母音の調音動作を混 同して発する患者は, 一周舌口蓋弓に影響を及ぼす関係 で，アの母音がつく子音に於て尤も多く，障害を起すも のと考光られる.

要するに, 舌の調音動作の形態が舌口蓋弓に影響を及 ぼす程度の大なる音が，吃音となって現われ易い関係が あるといいたい。

以上の見解の許に，舌口蓋筋に局処麻酔剤を注射して 見ると, 麻酔期間中には吃しないととが実証された。
矯正荧受け全治せぬ患者 600 人中ア母音の吃する種類

$\begin{array}{lr}\text { 夕音 } & 94 \\ \text { カ } & 93 \\ \text { ア } & 34 \\ \text { ナ } & 16 \\ \text { 八 } & 4 \\ \text { ヤ } & 3 \\ \text { マ } & 2 \\ \text { ラ } & 2\end{array}$

$\%$

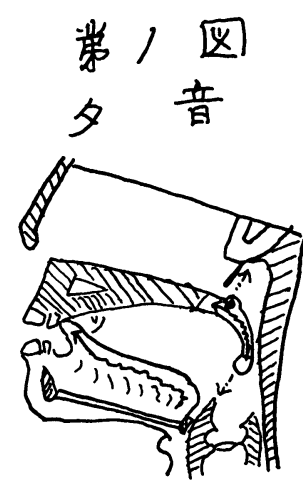

踢2四
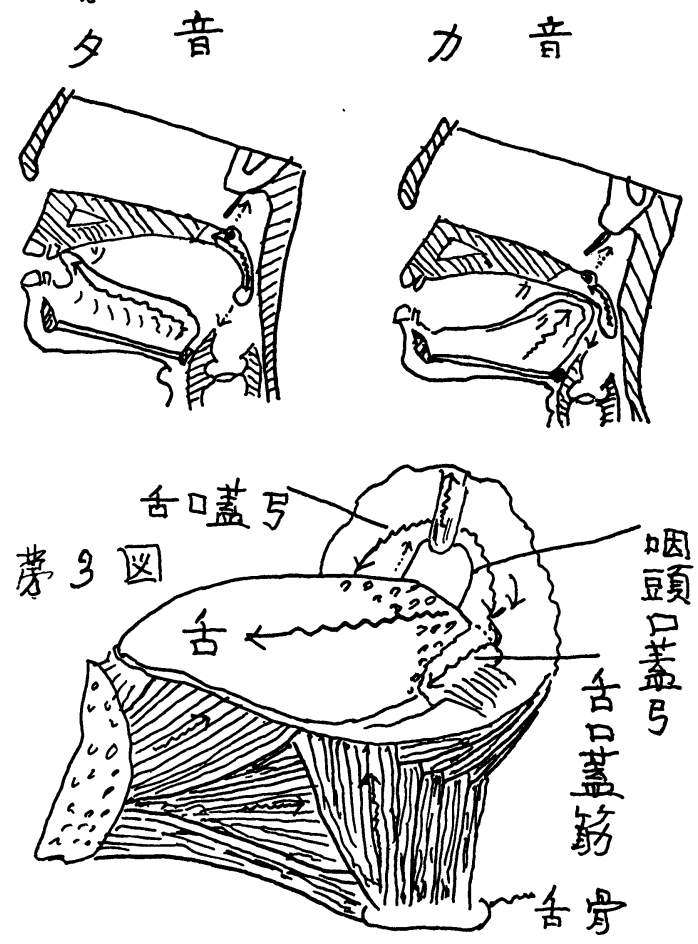
31. 嗄声における音声の雑音性に 関与る研究

柳原尚明

（京 大）

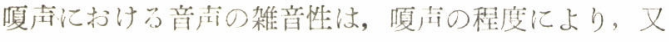

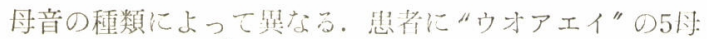
音荧連続して発南させた埸合の Sonagram の雑音分作,

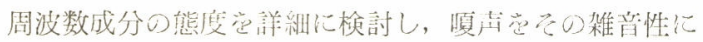
より次の $4 つ の$ 型汇分類した。

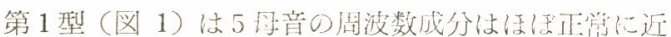
く保たれており，雑音成分は主ししてホルマント内に限 局して存する。

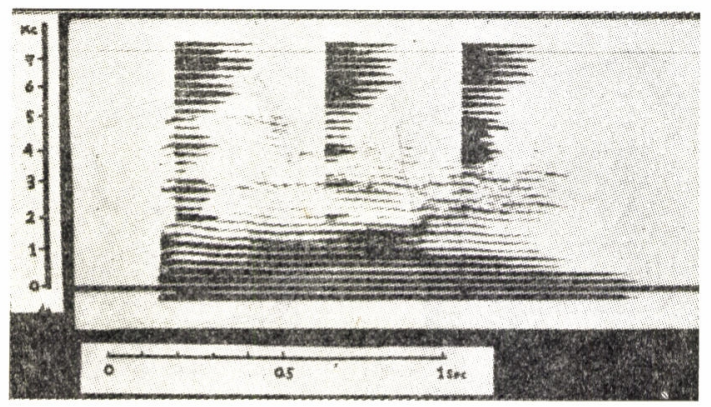

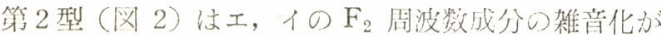

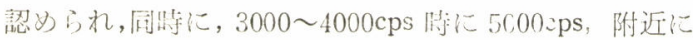

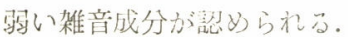

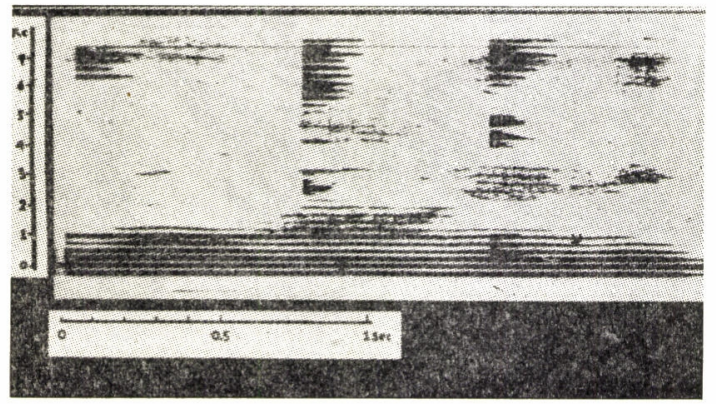

第3 型 (図 3) エ、イの $\mathrm{F}_{2}$ 周波数成分の完全な雑音 化が起り, $3000 \mathrm{cps}$ 以上の高周波域に雑音勢力の分布が

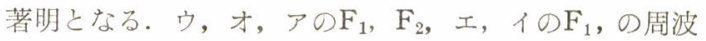
数成分は尚保存されている。

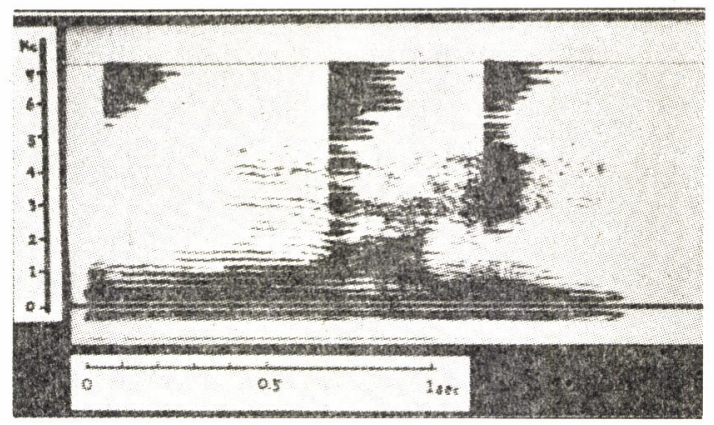

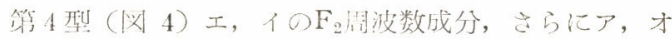
沙にウの $\mathrm{F}_{1}, \mathrm{~F}_{2}$ 周波数成分迄雑音化与る. $3000 \mathrm{cps}$ 以上

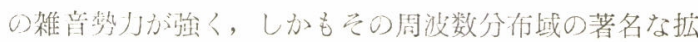

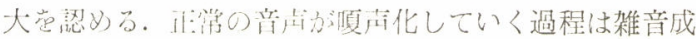

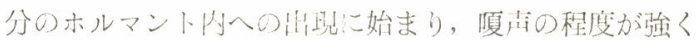

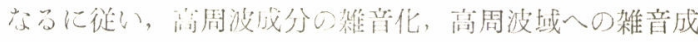

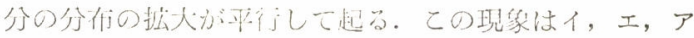
特代イと土抬い。

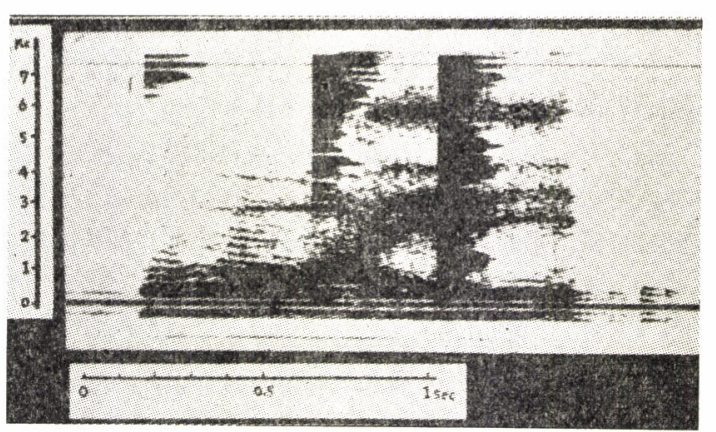

演者は，第 4 回，5茜回本学会で発表した嗄声の合成実 験, 及び, 今回述べる分析実験の結果上り, 嗄声の雑音 性の評洒流，ウ，ア，エ又はイの周波数成分，雑音分布 の態度荧検討する事に上り可能である事觉述べる。 
32. 口蓋裂音声の Sonagram による 分析と発語明瞭度との 関係について

\section{広戸幾一郎 ○平野 実}

(久 大)

口蓋裂音声患者 10 名（男女各 5 名，完全裂 3 名，不它 全裂 2 名, 手術施行済 5 名）につき，单音節 67 浯音の Sonagram 作製, 同時に20名のクルーにより発浯明暸 度を調へ，両者の関係学追求して次の結果总得た。 今回は子音の異常性について主として述べる.

Sonagram 上の子音の変化法次の如く江琶“出来乃.

〔I〕先行波の変化

(1) 欠如.

(2) 短縮或は微弱化.

(3) 変形.

〔II】子音波の変化

(1) 欠如.

(2) 不明瞭化或忚微弱化.

（3）他の子音波への転化.

(4) 変形.

〔III]移行部の変化

(1) 欠如.

（2）鮮明化又は不鮮明化，

(3) 短縮又は延長.

(4) 無声子音々節の移行部と有声子音々節の移行部 （両者は pattern が買なる）との相互転化.

従って実際の音声は之等が種々に組み合わされて多種多 樣の pattern 党示す。

一方発語明瞭度の上からは次の 3 つに分けられる。

(1) 正しく聴取されるもの.

(2) 他の語音涪って聴取されるもの.

（3）如何なる語音とも判し兼ねるもの（クルーの解答 は分散する)。

正しく聴取される語音, 他の語音に誤聴される語音は その語音と同じ pattarn の Sonagram を示すものであ るが，正常者のそれとはやや異なった pattern を示す場 合が少くない，之は自然度の低下の一つと考光られるも ので, 明膫度はよくても何か奇異の感を与えるものであ る. しかし一方, 言語治療に際して完全に正常の語音が
得られぬ場合, 次善の目標とし得る語音でもある。 明膫度検査で如何とも判じ難いものは Sonagram 上 でも複雑な変化をしている.

以上について Sonagram および録音テープによる音 声散供する。

\section{3. 口蓋裂患者の異常発音について}

宫崎 正 浜健太郎 ○辻 忠良 高寄 昭 待田順治 小室 甲 (大阪大学崡学部第一口腔外科学教室)

乘唇，口蓋裂患者の閉鎖形成手術は1766年 Le,Monnier 以来多数の研究者に上り考案改良され，その形成手術的 闭銧仙略々完全化行なわれる様沈ったが，その機能的 修複は現在種々検討されている。我々は過去 2 年間大阪 大学菡学部附属病院口腔外科を訪れた患者 500 名の内 48 名（軟口蓋裂17名, 不究全口蓋裂 6 名, 完全片側性口蓋 裂16名，完全雨側性口蓝裂 9 名. 男子 31 名，女子17名） について発声時舅腔漏出気量, 吹気時菑腔漏出気量, 発 語音節明膫度試験及び異深聴取マトリッスを用いて術前 の発音状態の分析を行なった。

口蓋裂患者の発音估開放性率音が著明であるが，口唇 音「パ，バ」は周じ口監音で破裂音でない「マ」に，口 蓋音「タ,ダ, サ, ザ, ラ」は閌じく「ナ」に, 軟口蓋 音である「カ，ガ」は「ア」又は「八」と尔る。即ちそ の構音域に於ける音汇置換又心省略を起して通自音とな る.

次に発声時悬腔上りの漏出気量赏測定すると, 清音で は「サ>タ>ナ>カ」となり, 独音では「ザ，ダ>バ〉 ガ」となり構音域が後方にあるもの程漏出が少ない.とれ はうしろの構音域のもの程, 舌に上万鼻咽喉閉鎖の代償 が良く行なわれている事を示している。しかし発語音節 明瞭度試験に上ると「カ>タ>ラ>サ〉パ」と構音域が うしろにあるもの程䦓違い易いという結果からして, 発 声時轒腔漏出気量の多少でもって, 発語音節明瞭度を決 定づける事は困難である. 
VIII 群

基礎的研究 (4) 座長 鈴 木 篤 郎 (信大教授)

35. 前方より直視下に行なった 語音発声時上咽頭閉鎖 運動の検討（第 2 報）

高橋宏明 柳原尚明 ○牧本一男

東 文生 本庄 嗾

（京 大）

外鼻及び鼻中隔に生じた放射線癌のため, 外鼻・鼻中 隔切除及び右デンテル氏手術を余儀なくされたため，外 部より上咽頭を正面より直視するととが出来る様になっ た症例について，その語音発声時の上咽頭閉鎖運動苍，

16 ミリ 32 駒/分 映画撮影し分析した結果の一部は，すで そ昨年の本学会で報告した。

前回は 5 母音及び鼻音の単音節発声時について，上咽 頭の形態的変化を，上咽頭閉鎖運動の様式及びその時間 的経過について観察, 分析して報告したが，今回はその 第 2 報として，その他の子音・拗音及び連続音について 前回と同様の検討を加元，次の様な点について報告する

（1）語音発声時，上咽頭は一定の閉鎖度を保つのでは なく，常に少しづつ閉鎖度を変える.

この動摇効果 (oscillatory effect) は, 語音発声時の上 咽頭閉鎖に関与する軟口蓋及び上咽頭側壁の両者に共通 して認められる。

（2）連続音発声時には，後続音が母音々節である場合 と，子音々節である場合には上咽頭閉鎖状態は若干その 態度を異にしている。即ち母音の連続音の場合には，上 咽頭の状態は先行母音の形から後続母音の形にスムース に移行するが，子音々節の後続する場合には一時閉鎖度 を弱める。

（3）拗音発声時には，上咽頭閉鎖運動はその発声中に 一時閉鎖度を弱め, 後続母音発声に際し, 完全閉鎖が行 なわれる。

（4） m. n. をもって始まる拗音は，鼻音発声時と同様 に, 後続半母音, 母音発声中でる軟口蓋上咽頭側壁の運 動は不充分であり，鼻腔と咽頭腔の遮断は不完全である

(5) 子音々節, 拗音々節, 連続音々節について, その

発声時の上咽頭閉鎖運動の時開的経過の詳細についての べる.

36. 発声時気管前壁音に関する研究

(1) 音声のpitch と気管前

壁音の Spectrum について

柳原尚明 ○杉山治美 (京大耳鼻科)

昨年の本学会で発声時の気管前壁皮つの振動は次の様 な特異性を持つ事を述べた。(1)発声時の振動エネルギー は母音によって差が少ない. (2)得られる音には母音性が ない.(3)振動波形は音声の基本周期を明瞭に示す。

これらの性質と声門での音響インピーダンスは Vocal tract のそれより数倍大きく, 気管内の振動波形は上部 共鳴腔の影響を受けない事より, 気管内の振動波を経皮 的にとり出す事により声帯振動波に近似的なものを得る 事が出来ると考元られる. 我々はこの音を気管前壁音と

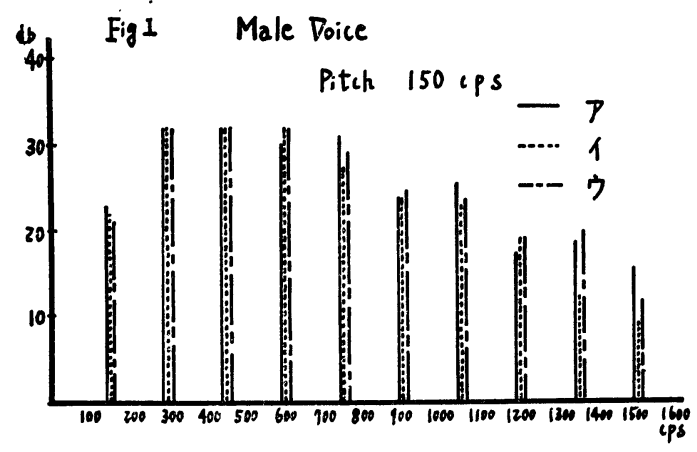

Fig 2 Male Voice, Chest Register

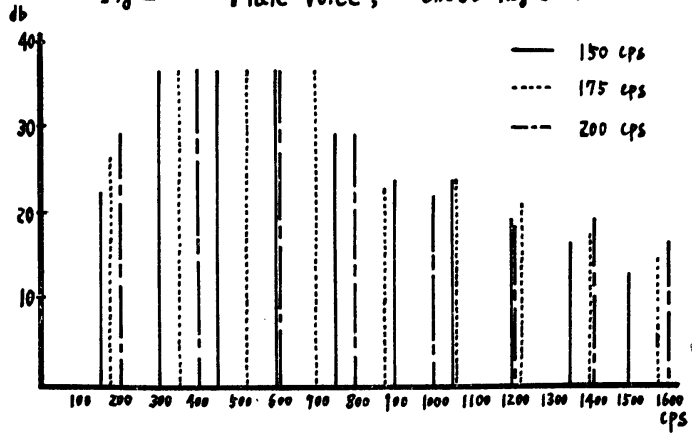


仮称し，音声研究における気管音の意義を検討している

本題では気管前壁者のSpectrum についての研究結果 を述べる. 実験は正常男女各 3 人について胸声区内で種 々の Pitch で発声さした場合の気管前壁音の Spectrum 分析を行なった. Mic は foster DF-1 (Dynamic) 特性 $100 \sim 12000 \mathrm{cps} \pm 5 \mathrm{db}$. を用い，録音は KP-3 型テープ レコーダー. Spectrum 分析は Sona-graph の Section によった.

Fig 1 は気管前壁音の Spectrum で, 母音によって差 のない事を示すものである. 又, 基音及び低周波域倍音 のエネルギーが強く, 以後次第に減衰する事, 特定の強 調周波数帯域を持たない事を示している. 経皮的に取り 出した音は $2000 \mathrm{cps}$ 以上に壮響ニネルギーを持たない.

Fig 2 は Pitch を変化さしても Spectrum に変化のな い事を示すものである.

気管の共振特性, 皮膚の Damping を考慮に入れて も，声門で生ずる音の Spectrum は個人について，母音 を変えても, 又胸声区内で Pitch を変えても変化しな いものと推察される．気管前壁音の分析は上の理由から 各個人の音声の特性を調査する場合の手がかりとして有 力な方法となりうるものである事を述べる.

37. 発声時気管前壁音に関する研究

（2）音声の基音波における

Amplitucle の变動について

柳原尚明 東 文生 ○細田岩雄 (京大耳鼻科)

発声時の気管前壁音の波形は基本周期が明瞭である. 口腔の前で得られる音声波形に比してその形は単純であ り, 一つの周期に対し一つの山を持つ波形, 即ち基音波 を与える.乙の波形の振幅は声帯振動の振幅と平行的関 係にある. 今回は正常男女 5 名について母音発声時のて の基音波の振幅の変動について検討した. 実験方法は, 気管前壁音を Confact M:c J T. 30 を用いて抽出し, K. P-3型テープレコーダーの Amp を通して, 電磁オッ シロに波形を抽化する。得られた波形の Amp li tucle を 測定した.

1. 定常部分: 波形包絡線中央部の 20 回の振動の平均
振幅, 及び振幅の最大変動を求めた. 最大変動值の分布 はほぼ正規分布を示し，平均振幅の4〜6\%である.

2. 立上り部分：第 1 回目からの振動の何番目に当るか を対数目盛に, 振幅を普通目盛にとると, 両者の間には 直線的関係が成立する. 振幅 $\mathrm{A}=\alpha \operatorname{logn}+\mathrm{C} \quad \mathrm{n}=\mathrm{ke} \mathrm{A} / \alpha$ $\alpha$ : 直線の方向係数, $\mathrm{n}$ : 振動の回数, $\mathrm{C}:$ Constant とな り, 直線の方向係数 $\alpha$ は立上りの急峻さを示す Indicator となりうる事が証明された. 普通の発声での方向係数の 平均值は表 1 の様になり, 推定平均值は12.56〜15.08で あった．ての值は硬起声で大きく，軟起声では小さくな る. 定常部の平均振幅の $90 \%$ 亿達するまでの振動回数は 表 2 の如くで平均回数 9〜12 回の範网にある. 発声の始 めの数回の振動は上述の直線関係党満足しない.乙の部 分を不規則部とすると, 不規則部の数は平均 2 ～回であ り, 発声時声帯振動か開始されて 4 回目迄はその Amplituele が不規則に動摇する事を示している.

母音発龂時の基音波における Amplitucle の変動は, 気管前壁音の波形の分折により客観的に表現しうる事が 可能である事を述べる.

\section{立上り部分（表Ｉ） \\ 5 母音発声時の方向你数平均值}
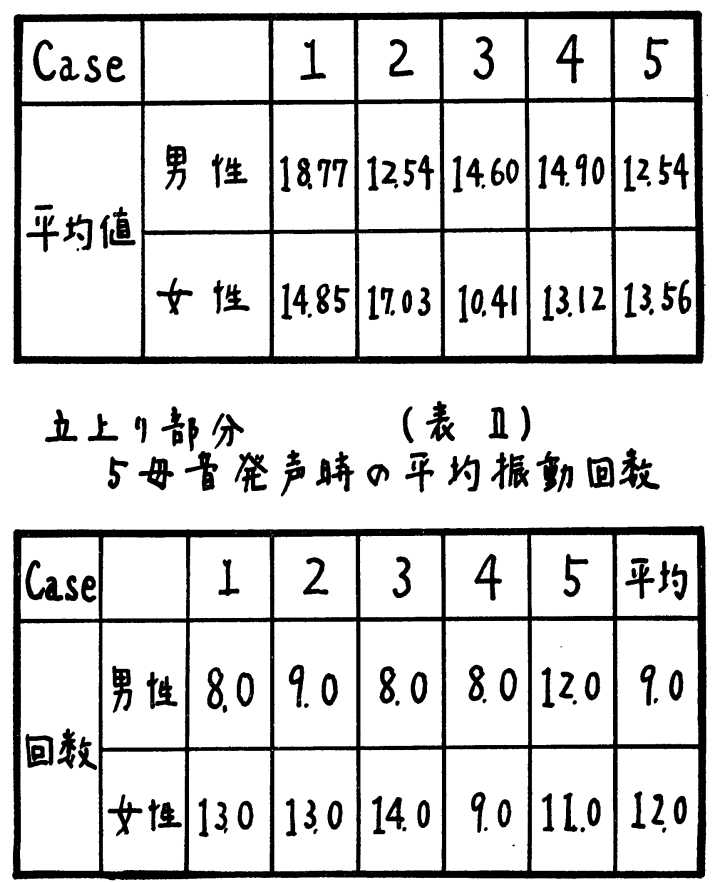


\section{8. 体位および頭位の音声に およぼす影響について \\ 公戸幾一郎 平野 実 $\bigcirc$ 太田黒延寿 (久留米大)}

体位および頭位を変化すると音声任影響が及ぶ事は周 知の事実であるが, 我々はこれを種々の面より検討して いる. 今回はアマチュア合唱団々員を対象として正常者

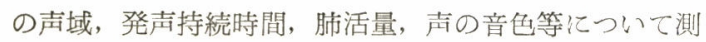
定観察した結果を報告する.

尚. 体位としては直立体, 腰掛位, 30度後傾位, 60 度 後傾位, 仰卧位, 伏臥位, 喉頭直達鏡位, 間接喉頭鏡位 の8体位, 頭位としては正常, 前属, 後屈, 右傾, 左傾 右旋, 左旋の 7 頭位苍取らせた.

主なる成績は次の如くである。

(1) 肺活量は殆ど影響されない.

（2）発声持続時間は胸声，頭声共，頭位の変化による 影響は殆どみられないが，体位の変化では仰臥位，伏臥 位, 喉頭直達鏡位, 間接喉頭鏡位等において短縮する。

（3）声域は直立体および腰挂位以外の体位, 又, 前屈 後屈, 右傾, 左傾でやや狭くなる.

（4）音色は各頭位および体位で変化するが，之は録音 テープおよび Sonagram により供覧する。

39. 音声の止声部における 性差について

○高橋宏明 柳原尚明 林 律 東 文生 (京 大)

音声の性差には, pitch 以外偣色の差も関与してい る. 音色には多種多椂な要素があるが; 今回はそのうち 起声部と止声部の振動様式, 特に, 止声部の声差につい て報告する。

第 1 図の上半は男声，下半は女声で，夫々の上の波形 は頸部誘導音下は音声波である。頸部誘導音は，かなり 声帯振動原波形に近いものであって，その振巾は発声開 始後次第に増大し, 一定の大きさに達して持続し, やが て次第に減少して終っているのが見られる，ての振巾増 大部を起声部, 一定の大きさで持続する部を定常部, 減
少部を止声部と称する事にする。

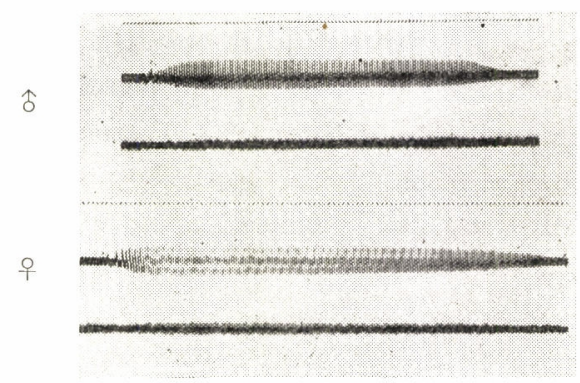

第 1 図からわから様に，男声は起声部代於て比較的急 激化振巾が增大し, 止声部では急激汇減少するに反し, 女声では両部其に比較的なだらかな增減觉示している. いま定常部の中央に於て西带振勒20個の振巾在測定し， この平均值学各サンプルの定常部振巾と定める。次化起 声部に於て仗発些開始より振门か淀常部振门の90\%に達 するまでの振動回数堂求めると, 男女声各5種の平均值伈 男声9.0女声，12.4である。即ち女䒠の方が軟起声の傾向 学有するが，その差盖著明ではない。一方，止声部に於 ては音声終了点より逝算して定常部振巾の $90 \%$ 亿達する までの振動回数觉求めると, 男声平均 14.4 , 女声平均

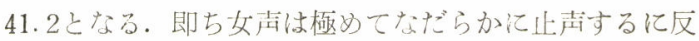
し，男声法比較的急激に止声する事荧示している．第 2 図㹥典型的な男女声各 1 種の止声部ソナグラムを示す.

更に，女声でも止声部振動回数が此挍的少ないものは 男声と判定されやすく, 又逆化男声で止声部振動回数が 比較的多いものは女声と判定されやすい事も立証される

即ち, 音声の性差を決定する音色としては, 止声部 振動様式が重要な役割を演じているものである.

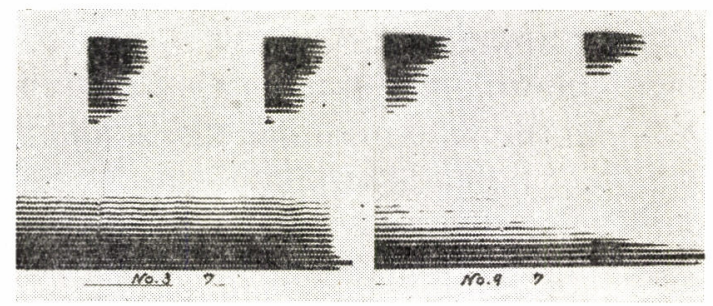




\section{IX 群}

音声障害の治療経験 座長 後 藤 修 二 (名大教授)

40. 吃り矯正の精神的原理と 実際について

望月庄一郎

（東洋語正学院）

私はかつて, 千葉大の望月衛氏から, カリフォルニア 大学で編集された,「吃音の重要な理論と治療」を借りて 読んだ. そして，その25氏による論文の内容を知った。 そのなかで，C・ブァン・ライバー氏は,「世界の吃りの 研究に心がけている殆んど全部が，対症的である.」と述 べていたてとに同感である. 従って，その理論がまちま ちであって, 抽象的で何ら具体的な解説がない. そして その理論と療法の実際について多くの矛盾があることは 日本の場合と共通している.

てれは根本的に吃る原因を何も知らないというととを 示しているすのである.

吃る原因と誤診された表情運動

吃りの状態は, 吃るてとに困って起される物品両面に 表現される現象であって，吃る原因ではない．即ち，吃 りに対する吃者のもつ羞恥心の有無強弱如何によって, 突発・連発・沿発・難発・中阻の状態に変るのである.

てのために，幼少年の吃りは突発運発となって音と共 に表現される。 この状態による客観的な判断が，吃りは 幼少年に断然多いという臆説をつくりあげたのである.

大人になるに従って羞恥心が強まり，発言に際して訾 躇・逧巡・停止またはその言葉を忌避し, 始発音の前に 発音可能と思われるアノーとかエーなどの言葉を補助的 そやる.

この吃者の心理を知らない人達が，大人になれば，自 然治ると誤解するのである.

吃る原因を，痙攣に因るものと誤解されるのは，ての 吃ると感じた瞬間，その音に対して躊跲逡巡する，ての 間, 発言の意思が綝返し続く限り，その音を構成する筋 肉のみが，ての反射運動となって連続的に表現されるの である、故に，その発言をやめてしまえば，呼吸・筋肉 の反射も・脳波・脈膊・血圧などの生理的異状反応は直 ちに正常となる。
ぞもりになった動機

吃りになる動機としての原因と, 吃る原因とは全く異 なったものであって，その動機とするものの $90 \%$ は模做 （意識的または無意識的即ち感化）であって，他の10\% はショックまたは，熱病中における内部的刺戟に因るも のである.しかし，その動機が何であっても，吃りとし ての現象を経験したという事実には変りがない．ただ問 題は, ての吃りとしての無意識に行動を起すようになっ たその原動力が何であるか，どてを根源として発動され るかというととである.

吃る原因

私は,「吃りは, 発言に際して均衡を欠いた無意識的行 動に因る生理的反射運動である.」と断言している. 普通 人においても，発言に際し，右か左りかと戸惑ったとき また何かショックを受けた場合に吃る時がある。

吃る原動力は, その意識し発言せんとする言葉を乗せ て無意識的に行動する, 即ち流れの調子に於ける角度に するのであって，その間合のない，秩序を欠いた無意識 的行動としての調子である刺战が, 音を構成する筋肉に 行動されたとき, 均衡を保持せんとする生理的機能が, これを受け入れるととをせず反射運動を起すためであっ て, 発言せんとする意思が, 連続的に繰返されると同時 に，乙の均衡を欠いた無意識的行動としての流れが連続 的に繰返されるときは, 反射は一回のみでなく, 連続的 に反射運動として起される。乙の表現された状態を吃り となづけたのである.

吃りの矯正について

ぞもりを治すには，ての吃る調子，吃らない調子のう ち, その発言に際して, 常に吃らない調子を先手, 先手 に行動させるととによって, 強い吃りも, 初日の指導僅 か40分以内にて, 普通人の速さで自己紹介と質問に対し 吃らず答光る。乙の事実は, 日附と共にその全部がテー プに録音されている。 


\section{1 級吃音者の 1 治験症例報告} （第 1 報）

\section{黒木安俊 ○佐藤伊吉 花沢忠一郎 荻野利之} （花沢研究班）

ここに報告する 1 症例は, 花沢研究班の治療方針に従 い, 短期間に完全治痖したもので, 年少の吃音者を持つ 家庭の人々に良い参考之考光報告する。

患者 満 3 才 男性 父37才 公務員 母 34 才 無職

(1) 吃音者の生活環境

田舎の辺地にある療養所の官全に住み, 昼間は父が勤 務のため夕刻まで州らず終日, 母親に従属して過し, 豊 富に与えられた玩具で我儘な遊びをしている。

(2) 吃音者の性格

患者は 1 人子のため, 甘やかされて育ち, 意志の弱い 内向性の子供である。

（3）母親の躾

母親は非常に虚栄心の強い勝ち気なヒステリ一性格で 近隣の評判は余り良くないといわれる。 また子供付対し ては要求されるままに物を与える反面, 子供に関係のな い不満の事も理由なく子供に当り, 全く盲目的な㷣を日 々繰り返している。

(4) 吃音になった動機

母親が自分の生家に帰った時に子供に甘納豆を与えた 時に「お豆」といって, そこの家の子供に笑われ, 甘納 豆と訂正された。平素は自分の家では母親に甘納豆を「お 豆」と教えられたのに笑われたのが非常にショックとな り，加えて 3 日間の滞在中,甘納豆という言葉を使わせら れ「アーアーマナットウ」と吃るようになり，それ以来 すべての言葉が吃り始めるようになった。

(5) 治療方法

(1) 両親の早口の会話をゆっくり話すように注意した

(4) 母親自身の吃音の誘因となるべき事を，すべて改 善させるよう指導した。

(2) 年令的に難しいと思われる言葉を使わせなかった

$\Theta$ その他，吃音矯正上に悪いと思われる事項を徹底 的に改めさせた。

困吃音者に対しては，興味を持たせるために好きな 絵本, 玩具の名称を発音練習の材料とし，短時間に実施 して 7 日間，連日，吃音者の家で矯正した。その結果， 7 日目には完全に治瘾した.
考案

幼児〔花沢研究班では 1 級吃音者と称す〕は成人〔 2 級吃音者】と異なり, 本人だけが治療しても絶対に治癒 するものではない, 両親, 特に母親自身の生活態度, 子 供に対する躲を改善するのが治療の第 1 段階である。吃 音者自身の治療は勿論, 重要な事であるが, 前述の事項 を改善することが吃音を早く治癒させるものである。

42. 余等の吃治療に使用している

発語法の原則とその意義

○佐藤伊吉

(千葉大)

花沢忠一郎 荻野利之 黑木安俊 今関好晴 (花沢研究所)

吃とくに私どもが 2 級吃と称する成人の吃では，心理 的吃といわれる程, 心理面の原因的要素が大きい，吃で は単に発語の場合に限らず精神安定を平生から計ること が，ひいては発語時の精神安定に当然関係する，平生の 心がけに「心は常に平静に」と第 1 条にかかげてある. 対人関係で吃の人に必然的にからんでくる劣等感, 羞恥 ，不安恐怖の是正は二級吃治療の半面であって，てれは パーソナリテーの問題であり, 吃者の性格改善には各個 人に則した環境, 肉身の問題とともに種々な心理的な困 難を伴ない, 指導者の能力の大部分はこれで決定される が，とてでは言及しない。

吃治療上，私どもは発語に関して原則たるものをかか げている.

（1）下腹に力をいれること

（2）気流を流すとと（息をとめないとと）

（3）第 1 音を延長するてと

である、下腹に力を入れることは，充分な吸気から，呼 気保持の腹式呼吸意識的にやらせるのであって, てれ は発語の不可欠の要素であるとともに, 精神安定に役立 つ. 気流を流すのは発語の失敗（吃）に対する不安のた め呼吸を止めるのを防止するのである. 発音は不安のた めできなくとも，無音に気流 (呼気) を流すととはでき るから，気流によって第 1 音を誘導する．語の第 1 音は 
発語（動作）のスタートの意義をもつが，吃ではこれが 不安緊張のため阻止するか, 爆発的にでてとぎれるか, 連発するかである. 第 1 は甚しく短縮して眻跌するから 第 1 音を充分延長して第 2 音に移行させる.

しかし吃の人は,ての三原則を使っても吃るととを恐 れて容易に三原則が使えない，それに対して「成否不問 一片の勇気」という標語をかかげてあって, 三原則への 踏み切りを容易にする. 三原則の実行には精神的な要素 と発語の機械的な要素とが盛られているから，てれを中 心として練磨するてとが極めて有効である.

三原則は吃者にはなかなか使用できないが，失敗(吃) した場合, それを切り抜ける唯一の切札である.たとえ 10回が10回まで成功せず，1回でも 2 回でも成功すれば 発語に自信を得，不安はそれだけ減少する。三原則の使 用が容易になる. てれが吃者の性格の改善と表裏一体と なって吃は治って行く．従来視話法をもじったハヒフへ ホによる第 1 音の誘導や，唱歌をうたうように不自然に 長たらしく発語する方法は, 実際の会話や他人の前での 読書には，吃がすぐ他人に知られるから吃者は決して使 用しない．また理論的にも，なるべく正常な発語を規準 とする私どもの考光からすれば，そういう方法は冗漫で 不合理である. 第 1 音の延長は吃の人には最初甚だ不自 然感じられ，なかなか延長できないが，うんと延長し たつもりでも正常に近いてとが多く，たと光長すぎても それでしゃべれるようになれば，正常にするには決して 骨折れることではないのを実際に見ている.

\section{3. 種々の薬剤による音声治療経験}

蔵内祥博 小林武夫 岡村正美 (東大音声・言語障害科)

東大耳鼻咽喉科音声外来で, 難治な喉頭疾患に対し, 新しい薬剤による治療効果を観察した。

(1) 反回神経麻痺及びいわゆる内筋麻瘦に対し A T P (adenosine triphosphate) 20mg 静脈注射による連日投 与.

（2）嗄声を主訴とする，慢性喉頭炎を中心とした喉頭 の炎症性疾患 亿 1-phenyl-2- (p-hydro-oxyphenyl-3.5dioxo-4-n-butyl-pyra zolidine mono-hydrate (以下 T用と 略す）を 1 日400mg〜 600mg 経口投与.
（3）嗄声を主訴とする慢性喉頭炎に対し，酢酸デキサ メサゾン (1回 $1.7 \mathrm{mg}$ ) の吸入療法（連日または隔日).

以上 3 つのグループに分け経過を観察したが, 患者は 昭和 37 年 4 月いらいの男 20 名, 女31名計51名, 年令は 5 才より72才迄でうち A T P 使用例19名, T剤17名, 酢酸 デキサメサゾン15名である.

治療経過判定には次の諸点を基準とした。

(1) 自覚的症状の変化. (主として嗄声.)

(2) 他覚的症状のうち, 声帯所見の变化. (浮腫,充血)

(3) 音声学的所見の変化. (話声位, 声域.)

その他, 反回神経麻瘦に対しては筋電図を記録した。

各グループ毎に比較的有効と思われた症例を二三呈示 したが，概要は

(1) A T P

(a) 反回神経麻痺では，自覚的によくなったものは多 いが, 他覚的には半数において声域, 発声持続時間に改 善をみ，披裂軟骨の可動性の恢復を見たものであった。

(b) いわゆる内筋麻㾝では, 自覚的にやや改善を見た もの $1 / 3$, 他覚的にはあまり改善が見られなかった。

(2) $\mathrm{T}$ 剂

保存的に治療したもの及び同時に手術的療法を兼ね行 なったもの，いづれにも嗄声の改善があり，他覚的には 声帯の充血は改善されたが, 浮腫に対しては余り効果は なかった。

(3) 酢酸デキサメサゾン

嗄声, 声带の充血には著効があったが, 浮腫が改善さ れたものは少数であった。

44. 複雑な慢性喉頭 (声帶) 炎の

手術的療法と音声の

予後について

法水正文

(東京聥信病院)

日常臨床で比較的多くみられる発声障害 (㖽声) を主 訴とする喉頭炎には各種のものがあるが，ての内複雑な 機質 (形態) 的变化を示す声帯並化仮声帯炎に対し, 主 として手術的治療法を施した場合の音声の予後について 
経験症例を述べる，ての場合には腫焬や特殊炎症等に因 るものは除き，主として voice abuse や miss use によ る炎症性変化或は洀痕性変化を来したものを主体とした 以上の様な範囲に入るものを喉頭鏡所見を主として次の 様に分けてみた。

1. 音声衰搦症

2. 単純性炎症

3. 単純性ポリープ

4. Sog Internusparäse

5. 広沉性肉芽浮腫性肥厚性慢性声帯炎

6. 所謂謡人結節

7. Sog Sulcusbildung を来した声帯炎

8. 声門下緣多発性ポリープ

9. 慢性肥厚性仮声帯炎

10. 声門横隔膜形成症

11. 声門下腔肉芽症

以上の内 $1-4$ 迄及び11には今回はふれない，其他の 5 一10迄の手術治療を主とする30例以上の音声恢復の経過 及び予後について概括すると，てれら症例では適当な手 術により音声が正常に恢復するのが普通であるが，少数 例では不成功であった。一般に嗄声の履歴の長いもの程 術後の音声恢復も遅れるのが通則である.

\section{5. 歌手の扁摘は絶対忌禁か？}

\section{須永義雄}

（虎の門病院）

歌手に対する扁桃摘出術は禁忌とされている，それは ての手術に際して口蓋弓の筋肉が傷けられ，その結果， 声楽発声に際し音色の形成に微妙な関係を有する軟口蓋 の調節機能が，多かれ少なかれ損われると考えられるか らである。

いっぽう若年の歌手や声楽学生で，慢性扁桃炎を主因 とする音声障害に悩むものはかなり多い。しかも普通の 患者ならば，ちゅうちょなく扁摘の対象と考光られるも のが少なくない。

演者は従来，歌手あるいは歌手志望者の慢性扁桃炎に 対して, 切除を行ない得るものは切除術, 切除不能のも のまたは切除残存部の炎症にはラドンシードの挿入を行
ない，摘出術は採用しなかった。しかし放射能の効果は 多くは比較的短期間に止まり，すぐれた治療法とは考え 難い.

そこで, 昭和35年度以来, 慢性扁桃炎のために声の使 用が甚しく制限され，あるいは扁桃を残置すると更に声 の障害の増悪を招くと懸念される例について，慎重な考 慮のうえで摘出術を試みているが，案じたよりよい成績 を得ている。

現在までに未だ 5 例しか経験しないが，扁摘の声に及 ぼした影響，手術の術式，手術摘応患者の選択などにつ いて論じ，未完成の歌手の扁摘は場合によって絶対禁忌 ではないという意見を述べた。

34. 難聴学級児童の言語障害について

(VII群補遣)

高原滋夫 東川清彦 ○長尾鴨三 (岡山大)

難聴学級児童19名中 8 名に言語 (発音) 障害を認め, そのうち 3 名は高度で 5 名は軽度であった。 てれらの発 音障害児について, 聴力損失の程度, 聴力の型, 聴力損 失の時期知能の程度について述べ, 補聴器を使用し. 更 に口形の指導，ストローなぞの器具を用いた発音指導を 根気よくやれば，高度障害児でもかなり効果があり, 又 知能の程度による影響がかなりあるととが分かった。 